\title{
ОТНОШЕНИЕ К МЕРАМ СТИМУЛИРОВАНИЯ РОЖДАЕМОСТИ ПО ДАННЫМ МИКРОПЕРЕПИСИ 2015 Г.
}

\section{ОЛЬГА ИСУПОВА}

\begin{abstract}
Статья посвящена оценке возможного мотивирующего потенииала мер семейной политики, перечисленных в анкете Российской микропереписи 2015 г. (МКП-2015). В течение последних десятилетий рождаемость в России не обеспечивает уровня простого воспроизводства. Государство, начиная с 2005 г., выражает озабоченность как можно более эффективными мерами, с помощью которых можно было бы добиться роста рождаемости. Микроперепись среди прочих задач имела целью “тестирование” привлекательности для населения как уже существуюших (федеральный и региональный семейные капиталы, выделение участка земли), так и на тот момент гипотетических (продление оплачиваемого отпуска по уходу за ребенком до трех лет, гарантированное место в детском саду, пособие в размере прожиточного минимума на каждого ребенка, начиная с третьего, налоговые льготы, гибкий график/надомная работа, беспрочентная ссуда на покупку жилья) мер семейной политики с точки зрения решения родить еще одного ребенка.

Исследование различий восприятия предлагаемых мер по полу, возрасту, уровню образования, месту жительства, числу уже имеющихся и желаемых детей, а также по статусу занятости методами дескриптивной статистики (поскольку индивидуальных данных нет в прямом доступе на сайте МКП-2015) показало возможную кластеризацию женщин (отчасти и мужчин) на тех, кто настроен на только одного, двоих или троих детей. Меры, ориентированные на третьего ребенка, не интересны первой и второй группе респондентов. Наиболее популярной среди практически всех категорий оказалась беспрочентная ссуда на жилье. В иелом позитивно воспринимаются меры патерналистского характера, наименее популярны надомная работа и налоговые льготы, возможно, потому, что первая ассоииируется с более низким заработком, а вторые интересны только при занятости в “белом” секторе экономики. Ориентация на троих детей прослеживается в основном у женщин с более низким уровнем образования и в сельской местности.
\end{abstract}

Ключевые слова: Российская микроперепись 2015 г., аналитические ограничения, репродуктивные намерения, семейная политика, эффективность.

\section{ВВЕДЕНИЕ}

В течение последних десятилетий рождаемость в России не обеспечивает уровня простого воспроизводства. Поскольку с этим связан ряд не только демографических, но и экономических проблем (старение населения, увеличение демографической нагрузки людьми старшего возраста на работоспособное население, и др.), государство постоянно, начиная, как минимум, с 2005 г., выражает озабоченность ростом рождаемости и как можно более эффективными мерами, с помощью которых можно было бы этого добиться.

\footnotetext{
ОЛЬГА ГЕНРИХОВНА ИСУПОВА (oisupova@hse.ru), НАЦИОНАЛЬНЫЙ ИССЛЕДОВАТЕЛЬСКИЙ УНИВЕРСИТЕТ «ВЫСШАЯ ШКОЛА ЭКОНОМИКИ», РОССИЯ.

ИССЛЕДОВАНИЕ ВЫПОЛНЕНО В РАМКАХ ПРОГРАММЫ ФУНДАМЕНТАЛЬНЫХ ИССЛЕДОВАНИЙ НИУ ВШЭ В 2017 Г., ПРОЕКТ ДОЛГОСРОЧНОЕ ДЕМОГРАФИЧЕСКОЕ РАЗВИТИЕ В СВЕТЕ РЕЗУЛЬТАТОВ ВСЕРОССИЙСКОЙ МИКРОПЕРЕПИСИ НАСЕЛЕНИЯ 2015 Г.».

СТАТЬЯ ПОСТУПИЛА В РЕДАКЦИЮ В МАЕ 2018 Г.
} 
В 2006 г. была принята программа так называемого материнского (или семейного) капитала, согласно которой в связи с рождением второго или следующего по очередности ребенка (но для каждой женщины не более одного раза в жизни), семья получала сумму 250 тыс. руб. (впоследствии путем индексации доведенную до нынешних 415 тыс. руб.), которую можно было потратить только на улучшение жилищных условий, пенсию матери, образование одного из детей (в дальнейшем вариативность направлений использования была несколько увеличена, кроме того, почти во всех регионах были введены дополнительные аналогичные региональные программы, как правило, предусматривающие выплаты, только начиная с третьего ребенка и меньшие по объему - модальная величина их составляет 100 тыс. руб.).

Рождаемость (ее суммарный коэффициент - СКР) несколько выросла в отдельные годы, однако причины этого роста не все исследователи связывают с семейным капиталом (разные точки зрения на возможные причины увеличения рождаемости и роли среди них материнского капитала представлены, например, в работах [Захаров 2016a, b; Малева, Макаренцева, Третьякова 2017; Слонимчик, Юрко 2015]. Наиболее высоко оценивают роль маткапитала последние авторы, и все же прирост СКР, обусловленный этой политикой, составил, по их мнению, лишь 0,15. С.В. Захаров убежден, что в реальных поколениях роста рождаемости не будет. Малева, Макаренцева, Третьякова обращают внимание на утверждение большинства исследуемых женщин о том, что материнский капитал не повлиял или незначительно повлиял на их решение родить еще одного ребенка). В любом случае, поскольку в настоящее время рожать начинает малочисленное поколение 1990-х годов рождения, а также в связи с тем, что принятые ранее программы не привели к увеличению числа рождений первых детей, государство вновь выразило озабоченность возможными дополнительными мерами по увеличению рождаемости.

В связи с этим при проведении микропереписи 2015 г. (МКП-2015) в анкету для опроса были включены вопросы об оценке населением различных уже существующих и возможных будущих мер демографической политики.

Ответы на вопрос, содержащий в качестве альтернатив ответа перечень мер, включенных в анкету МКП-2015, которые могли бы повлиять на дополнительные рождения, уже проанализированы в Докладе Росстата об основных итогах этой переписи [Доклад.... 2016]. С точки зрения его авторов, наиболее популярными у респондентов остаются такие меры, как федеральный и региональный семейные капиталы. Однако в этом докладе анализ соответствующих ответов выполнен не в разбивке по всем возможным критериям, различающим респондентов между собой. Заполнить эту лакуну и призвана настоящая статья. С нашей точки зрения, семьи неоднородны, репродуктивный выбор в различных типах семей происходит совершенно по-разному. Мы собираемся изучить, как влияет на оценку различных мер пол, возраст, уровень образования, место жительства и некоторые другие критерии. 


\section{СЕМЕЙНАЯ ПОЛИТИКА: ТЕОРЕТИЧЕСКИЕ ПОДХОДЫ И ИССЛЕДОВАНИЯ}

Поскольку микроперепись 2015 г. состоялась относительно недавно, пока существует достаточно небольшой круг посвященных ей публикаций. Однако история исследований семейной политики почти столь же давняя, как и сама политика, и насчитывает больше столетия. Все оцениваемые МКП-2015 меры так или иначе, если не ровно в той же модификации, то в похожей, уже были где-то приняты или где-то обсуждались [Caldwell, Caldwell, McDonald 2002; Chesnais 1985; Ekert 1986; Gauthier 2002; Teitelbaum 2006; Исупова 2017].

Достаточно существенное денежное вознаграждение при рождении ребенка («бэби бонус») было, например, принято в Австралии с начала 2000-х годов, с первого марта 2014 г. эта мера была заменена на «Newborn Upfront Payment» и «Newborn Supplement»состоящая из двух частей выплата, в сумме на первого ребенка 2000 долларов, на второго ребенка и последующих по 1000 долларов. Налоговые льготы семьям особенно развиты и особенно давно существуют во Франции [Gauthier 2002], но не только там, например, в Австралии ${ }^{1}$. Ежемесячные пособия достаточного для жизни размера на детей разной очередности рождения также давно существуют в разных странах, но пионером и здесь была Франция [Gauthier 2002; Исупова 2016]. Беспроцентная ссуда на покупку жилья при соблюдении семьей определенных условий существовала в Германии в 1930-е годы, причем четверть ссуды «прощалась» семье при рождении каждого последующего ребенка, начиная с первого, соответственно, при рождении четвертого можно было ничего не выплачивать [Исупова 2017]. Гибкий график труда, совмещение должностей, работа неполный день особенно развиты в Нидерландах [Исупова 2016]. Надомная работа обсуждалась как мера для матерей в позднем СССР [Исупова 2017], но вопрос в том, что тогда не каждое предприятие могло обеспечить людей именно надомной работой, а в настоящее время матери в разных странах и так работают на дому, если у них это получается, но это не всегда их собственный выбор, скорее вынужденная мера ${ }^{2}$. Аналогичные надомной работе проблемы возникают и при профессиональной переподготовке матерей: появляются сложности с соблюдением баланса семьи и работы/учебы в период интенсивного ухода за маленьким ребенком [Серегина 2012; Зеленкова, Чернова 2012]. Детские сады как мера поддержки работы обоих родителей особенно хорошо развиты в Скандинавии и во Франции [Тындик 2010].

В целом меры поддержки семей делятся на прямые выплаты, налоговые льготы и меры социальной поддержки семей [Gauthier 2002]. Считается, что приоритетная роль прямых денежных выплат характерна для патерналистской модели семейной политики (в которой вмешательство государства в поддержку семьи максимально), которая когда-то (в период между двумя мировыми войнами) существовала во Франции, Италии, Германии, а в позднем Советском Союзе вплоть до его распада, хотя в СССР прямые выплаты всегда сочетались с системой детских садов [Исупова 2017]. Главной сущностной особенностью

1 URL: https://immigrant.today/article/9698-posobija-kak-avstralija-pomogaet-svoim.htm (дата обращения: 06.07.2018).

2 URL:https://www.miloserdie.ru/article/rabota-v-dekrete-ili-kak-prevratit-lyubimoe-delo-v-istochnik-dohoda/ (дата обращения: 06.07.2018). 
патерналистской политики является то, что государство при этом в существенной мере берет на себя «отеческие» функции по отношению к детям и матерям. Семьи в результате привыкают в вопросах деторождения в существенной степени полагаться не на себя, а на государство [Зеленкова, Чернова 2012]. Государство также может стараться минимизировать свое участие или делать его выборочным, помогая только особо нуждающимся [Kaufmann 2002]. По известной классификации Г. Эспин-Андерсона, первое характерно, например, для средиземноморского режима семейной политики, второе - для либерального [Espin-Andersen 1990]. При этом скандинавский (социал-демократический) режим из его же классификации, ориентированный на гендерное равенство и существование как значительных пособий, так и развитой системы детских садов, можно считать лишь отчасти патерналистским (объем вмешательства государства велик), но основная ответственность за сам уход за детьми и их воспитание остается на родителях. Исследователи не имеют однозначного ответа на то, какая система семейной политики является лучшей для семей и влияет ли вообще семейная политика на деторождение, хотя попытки это понять предпринимались неоднократно (существуют, однако, исследования, показывающие, например, что Скандинавские страны и Франция демонстрируют большую эффективность государственных услуг семьям (таких, как детские сады) по сравнению с прямыми выплатами [Thevenon 2008]). Есть проблема, как квантифицировать сами меры политики, которые не всегда легко сопоставить друг с другом (экономическая поддержка, поддержка женской карьеры, отпуск по уходу за ребенком, различные услуги для семей с разной степенью ценовой, временной и территориальной доступности и др.), а также какие выбрать индикаторы успеха тех или иных мер. Многие авторы (например, [Gautier 2002; Зеленкова, Чернова 2012]) считают, что главное, чтобы семейная политика в стране предполагала реальные меры по улучшению уровня и качества жизни семей в отношении жилищных условий, дохода, доступных услуг в области образования, медицинского обслуживания и присмотра за детьми. Если во всех этих областях происходят заметные улучшения, связанные именно с наличием детей, рождаемость в любом случае растет, но немного. Столь же незначительно (или даже в еще меньшей степени) она растет и в результате прямых выплат. Например, эконометрическое моделирование О. Экерт [Ekert 1986] показало, что даже полная компенсация расходов на ребенка в течение всего периода его взросления увеличит коэффициент суммарной рождаемости лишь на 0,5 . При этом на такую полную компенсацию не пойдет ни одно самое патерналистское государство. Таким образом, было выявлено, что эффект возможен, но не будет превышать сотые или максимум десятые доли коэффициента суммарной рождаемости, т.е. добиться увеличения рождаемости даже до уровня простого воспроизводства проблематично, скорее, может идти речь о том, чтобы повысить сверхнизкие показатели СКР менее 1,5 до «высоких» низких (СКР 1,7-1,8). К тому же получаемые в расчетах результаты в существенной степени зависели от применяемых расчетных методов [Кучмаева 2017].

Что же касается оценки эффективности недавних российских мер, например, принятых в 2006 г., многие работы показывают, что они повлияли скорее на тайминг рождений, чем на увеличение числа детей в семьях. Просто и без того запланированные дети появились на свет раньше [Андреев, Захаров 2017; Синявская, Бирюкова, Фаттахова 2015]. 
Тем не менее возможности дополнительного влияния на рождаемость в России с целью добиться ее роста продолжали обсуждаться. Довольно перспективными в последние годы считаются меры, связанные с возможностью для родителей работать по гибкому графику, что позволяло бы успешнее сочетать родительство и участие в рынке труда, к тому же уже понятна стала и острота жилищной проблемы именно в первые годы существования молодой семьи, а также актуальность для большинства родителей услуг по уходу за самыми маленькими детьми, позволяющих женщинам не покидать рынок труда в связи с материнством слишком надолго [Елизаров, Левина 2015]. Обсуждается также и дифференциация российской рождаемости по уровню образования, дохода, месту жительства родителей и потенциальных родителей [Елизаров, Левина 2015; Андреев, Захаров 2017; Синявская, Бирюкова, Фаттахова 2015]. На основе всех этих дискуссий и были выработаны наши основные гипотезы.

Во-первых, мы предполагаем, что для российских граждан в области политики попрежнему характерен запрос на патернализм, понимаемый как предпочтение монетарных форм помощи (это может проявляться в предпочтении федерального и регионального маткапиталов, беспроцентной ссуды на жилье). Это связано еще и с тем, что средние зарплаты во многих регионах недостаточны для обеспечения действительных нужд семьи, особенно, если в ней несколько детей. Как раз за IV квартал 2015 г. правительством был установлен в среднем по России прожиточный минимум 9452 руб., на взрослого - 10187 руб., на пенсионера - 7787 руб. и на ребенка -9197 руб. в месяц ${ }^{3}$. Среднемесячная зарплата при этом составляла 32439 руб. в месяц ${ }^{4}$ (по данным Росстата на октябрь 2015 г.). При одном работающем родителе (например, это только отец, а мать занимается воспитанием детей, или это одинокая мать) и наличии двоих детей средняя российская семья оказывается на уровне прожиточного минимума или ниже.

Во-вторых, предпочтение монетарной помощи будет в большей мере характерно для жителей сельской местности и с более низким уровнем образования. Для более молодых женщин с более высоким образованием будет более интересна сервисная помощь (место в детском саду), им будут мало интересны меры, направленные на третьих и более детей. В целом работающим, образованным и более молодым людям могут быть более интересны немонетарные меры политики, однако и они заинтересованы в выплатах в связи с невысоким уровнем доходов населения России.

Со времени проведения МКП-2015 прошло уже более двух лет. В декабре 2017 г. были разработаны и утверждены Госдумой меры по поддержке рождения первых детей в форме ежемесячного пособия нуждающимся семьям. Это одна из мер, обсуждавшихся в МКП-2015. Наш анализ позволит также показать, насколько популярной у респондентов была такая мера.

\footnotetext{
${ }^{3}$ Постановление Правительства Российской Федерации от 10 марта 2016 г. №178 «Об установлении величины прожиточного минимума на душу населения и по основным социально-демографическим группам населения в целом по Российской Федерации за IV квартал 2015 г.». 4 URL: www.gks.ru/free_doc/new_site/population/trud/sr-zarplata/t2.xlsx (дата обращения: 07.07.2018). 


\section{ПРОБЛЕМЫ МЕТОДОЛОГИИ И ИНТЕРПРЕТАЦИИ РЕЗУЛЬТАТОВ МКП-2015}

Переписи России уже критиковалась с точки зрения методологии их проведения [Андреев 2012]. МКП-2015, с точки зрения автора, также несвободна от проблем в этом отношении. Вопросы 24 и 25 микропереписи 2015 г., непосредственно относящиеся к репродуктивным планам, задавались только людям в репродуктивном возрасте, т.е. женщинам 18-44 лет и мужчинам 18-59 лет. Вопрос 23 о том, сколько у человека рожденных детей, задавался только женщинам 15 лет и старше. Число детей у опрашиваемых мужчин, вероятно, определялось на основании опроса о родственных связях в домохозяйстве. Формулировка вопросов о желанных и планируемых детях учитывает уже имеющихся детей.

При анализе нами было обнаружено, что в выборочную совокупность попало 628,649 тыс. мужчин в возрасте 15-59 лет и 432,984 тыс. женщин в возрасте 15-44 года (соответственно 580,366 тыс. мужчин в возрасте 20-59 лет и 386,194 тыс. женщин в возрасте 20-44 года). В то же время, отвечая на вопрос 25, предполагающий оценку различных мер семейной политики и в целом условий для рождения дополнительных детей, каждую меру оценивали около 48-50 тысяч мужчин и примерно столько же женщин. То есть в общей сложности каждую альтернативу ответа на вопрос 25 оценивали примерно 100000 человек. На наш прямой запрос в Росстат для разъяснения этого несовпадения мы получили ответ, что вопрос о мерах семейной политики задавался только тем людям репродуктивного возраста, кто в вопросе 24 отметил желание иметь больше детей, чем то, которое они собираются иметь. Соответственно, на него не отвечали все те, кто собирается иметь детей вне зависимости от мер политики или вообее не собирается, хотя в реальности политика при ее принятии затронет и их. Более того, вопрос 25 («Если вы хотели бы иметь детей больше, чем собираетесь, то в какой степени рождению желаемого числа детей могли бы способствовать следующие условия...») сформулирован таким образом, что он кажется адресованным абсолютно всем, даже в большей мере тем, у кого такого желания пока нет, в случае, «если» оно вдруг появится. В целом вопрос сформулирован с большой степенью неопределенности, он как бы не о реальных намерениях и планах, а о какой-то гипотетической ситуации, которая описывается с помощью одного «если» и двух «бы». Таким образом, в данном случае при ответе на вопрос 25 мы имеем дело с ограниченной подвыборкой мужчин и женщин репродуктивного возраста, с одной стороны, выразивших желание иметь больше детей, чем у них уже есть и чем они собираются в принципе, но с другой - отвечающих на вопрос, который как бы предлагает им поставить такое свое желание под сомнение. А ведь мнение всех остальных при оценке предлагаемых мер семейной политики, как минимум, не менее интересно.

Как бы то ни было, мы имеем большое число ответивших на вопрос 25 (почти по 50 тыс. мужчин и женщин при оценке каждой альтернативы) и можем проанализировать распределения их ответов по различным другим показателям из перечня вопросов анкеты, отдавая, однако, себе отчет в вышеописанных ограничениях этой выборочной совокупности. 
У нас есть возможность проанализировать оценку этими респондентами таких мер, как:

- возможность получения ежемесячного денежного пособия (предоставления оплачиваемого отпуска) по уходу за ребенком до 3 лет;

- возможность получения федерального материнского (семейного) капитала;

- возможность получения материнского (семейного) капитала, установленного в соответствующем регионе;

- возможность получения ежемесячной денежной выплаты на третьего ребенка в размере прожиточного минимума ребенка, установленного в соответствующем регионе;

- возможность без проблем получить место для ребенка в детском саду, яслях;

- налоговые льготы работающим родителям;

- предоставление семьям с тремя и более детьми земельных участков под строительство жилого дома;

- возможность иметь гибкий график работы (или неполный рабочий день/неделю, или дистанционно, на дому);

- возможность профессиональной подготовки, переподготовки и повышения квалификации в период отпуска по уходу за ребенком в возрасте до 3-х лет,

- возможность при рождении второго или последующего ребенка получить беспроцентную ссуду на покупку жилья площадью в размере социальной нормы;

- а также таких условий, как

○ изменение личных обстоятельств;

○ повышение жизненного уровня семьи.

Именно таковы формулировки альтернатив ответа в вопросе 25 . Все эти варианты оцениваются по 5-балльной шкале, в дальнейшем при анализе мы используем сопоставление средних баллов, выбранных для оценки этих мер различными категориями респондентов.

Можно видеть, что описание конкретных мер семейной политики в данном случае смешано с такими неопределенными и не измеряемыми однозначно условиями, как «личные обстоятельства» (как может повлиять на рождение ребенка изменение личных обстоятельств и каких именно? Даже если принять, что тут точно имеется в виду только брачность и ее изменения, одинаково заданный вопрос для не состоящих в браке может означать, что им надо вступить в брак для рождения ребенка, а для состоящих в браке развестись? Улучшить отношения с партнером? Выйти замуж за другого? Остается только догадываться...) и повышение уровня жизни в связи с любыми событиями, частью которых, в общем-то, могут стать и выплаты в контексте семейной политики.

В связи с такой повышенной логической неопределенностью мы решили исключить эти условия из дальнейшего анализа, поскольку результаты нельзя будет однозначно интерпретировать.

Мы также исключили из анализа альтернативу о профессиональной переподготовке, так как опубликованные Росстатом таблицы позволяют увидеть, что она оценивается респондентами наиболее низко, что соответствует известным из литературы [Серегина 
2012: 26-35] проблемам, возникающим для родителей при попытках распределить время на уход за ребенком и получение образования в любой форме, в особенности при ограниченных семейных ресурсах (например, когда ребенка не с кем оставить, чтобы посещать курсы, требуются деньги на проезд до места образовательной деятельности, неочевидна экономическая польза новой профессии в дальнейшей жизни матери и др.).

Итак, дальнейшее представляет собой анализ оценки респондентами девяти оставшихся социально-политических альтернатив.

Ограничения и некие логические несоответствия возникают и здесь, и при интерпретации нам необходимо принять их во внимание.

Мы должны осознавать, что участникам исследования в одном и том же списке предлагается оценить как уже существующие меры, такие как федеральный и региональный семейный капитал, ежемесячное пособие на третьего ребенка и последующих детей до трех лет в размере прожиточного минимума, существующее в большинстве регионов, предоставление земельного участка при рождении третьего ребенка, так и меры, которые только обсуждаются - продление оплачиваемой части отпуска по уходу за ребенком до трех лет, налоговые льготы, гибкий график/дистанционная работа, а также гарантированное место в детском саду/яслях (его наличия для каждого ребенка страны не так просто в реальности добиться).

Кроме того, когда вопросы о семейном капитале (федеральном и региональном) задаются людям, уже имеющим двоих-троих детей и уже приобретшим право на эти выплаты, не очень понятно, как они понимают соответствующий вопрос, ведь речь идет об их следующем ребенке (и нельзя исключить, что им представляется, что у них может появиться возможность получить такой капитал еще раз).

Тем не менее выбранные нами 9 семейно-политических альтернатив (федеральный материнский (семейный) капитал; региональный материнский (семейный) капитал; ежемесячная денежная выплата на третьего ребенка в размере регионального детского прожиточного минимума; беспроблемное получение места для ребенка в детском саду, яслях; налоговые льготы работающим родителям; предоставление семьям с тремя и более детьми земельных участков под строительство жилого дома; гибкий график работы (или неполный рабочий день/неделю, или дистанционно, на дому); получение беспроцентной ссуды на покупку жилья площадью в размере социальной нормы при рождении второго или последующего ребенка), на наш взгляд, можно подвергнуть осмысленному анализу. Ниже мы представляем его результаты. 


\section{АНАЛИЗ ВОСПРИЯТИЯ ПРЕДЛАГАЕМЫХ МЕР СЕМЕЙНОЙ ПОЛИТИКИ МУЖЧИНАМИ И ЖЕНЩИНАМИ, ЖЕЛАЮЩИМИ ИМЕТЬ БОЛЬШЕ ДЕТЕЙ, ЧЕМ ПЛАНИРУЮТ}

\section{Различия в восприятии мер семейной политики в зависимости от трудового статуса}

Рассмотрим сначала восприятие женщинами различных вариантов из списка предлагаемых мер в зависимости от уровня их образования и трудового статуса. В отличие от мужских оценок, данные микропереписи дают возможность увидеть различия в оценках женщинами мер политики в зависимости от числа рожденных ими детей. Это важно, так как образ жизни матерей с разным числом детей может существенно различаться, еще менее он будет похож на образ жизни бездетных женщин.

Первое направление аналитического разделения - наличие трудовой деятельности (рисунки 1,2). Наиболее низко и работающие, и неработающие женщины оценивают гибкий график работы, включая дистанционную работу на дому. Можно предположить, что это связано с трудностями при попытках сочетать работу и домашние дела в одном и том же месте и сомнениями в том, что получится выполнить и то, и другое качественно, при этом избежав перенапряжения и самоэксплуатации. Кроме того, низкая оценка такой меры, видимо, связана и с ожиданиями, что при этом и заработок будет меньше, чем при работе в течение полного дня. Интересно, что работающие женщины с разным количеством детей оценивают гибкий график несколько ниже, чем неработающие. Возможно, это связано с тем, что у них есть соответствующий опыт.

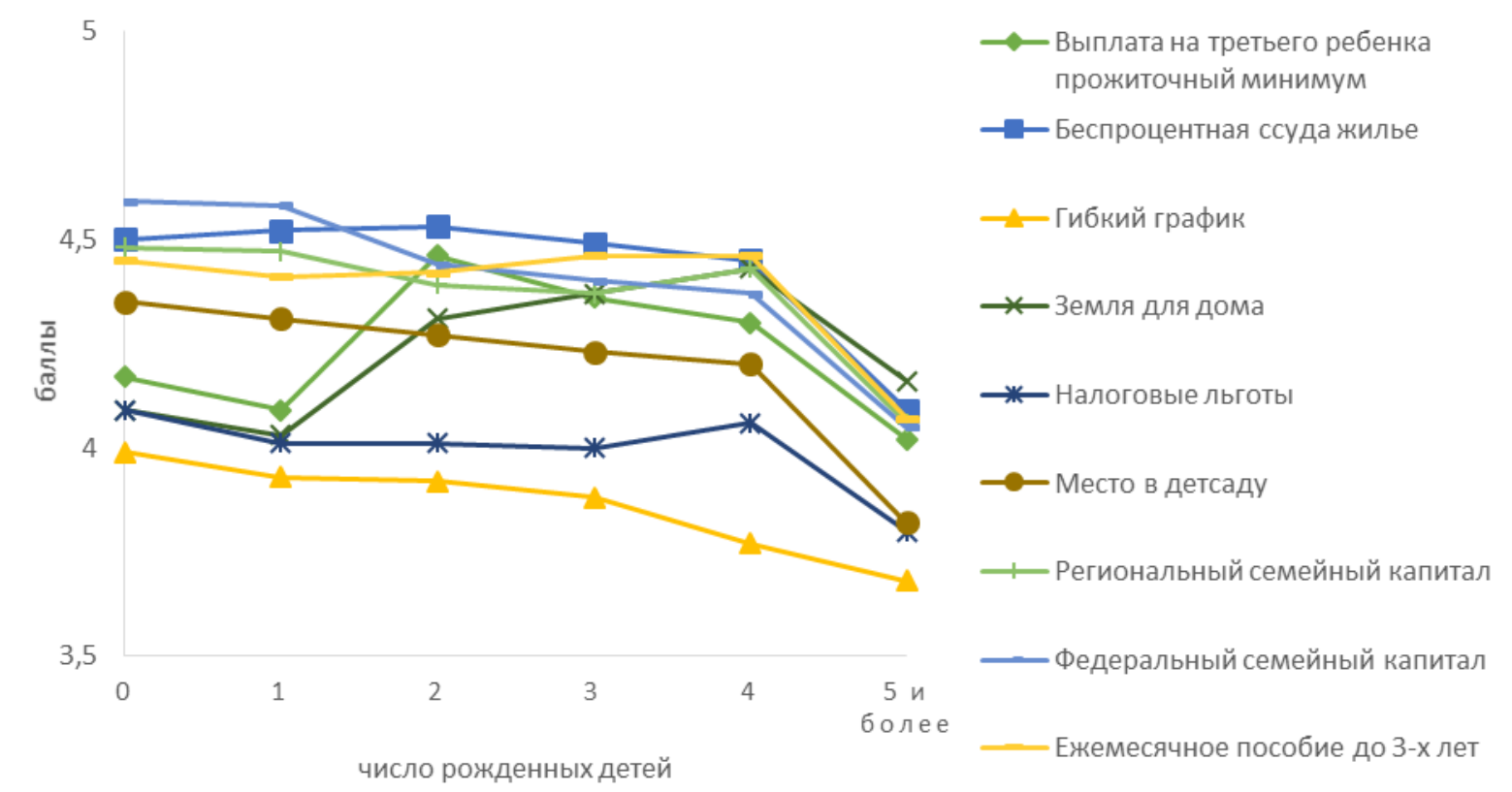

Рисунок 1. Оценка значимости мер поддержки семьи для экономически активных женщин в зависимости от числа рожденных детей, микроперепись 2015 г., средний балл 
Наиболее высоко оценивается федеральный семейный капитал вне зависимости от наличия у женщины трудовой деятельности, причем его оценка падает у матерей двоих и более детей (вероятно, они все-таки не верят, что смогут получить его еще раз). Региональный капитал оценивается немного ниже, а динамика оценок очень похожа.

У матерей двоих и троих детей в обеих изучаемых совокупностях лидирует оценка возможности получения беспроцентной ссуды на жилье, что может быть связано с остротой не только жилищного, но и ипотечного вопроса, с возможностью получения суммы, необходимой для приобретения семейного жилья приемлемого качества и приемлемой величины без многолетнего ожидания.

Резко увеличивается значимость выплат на третьего ребенка (и у работающих, и у неработающих) в размере прожиточного минимума у матерей двоих детей. Теми, у кого пока нет детей или есть только один ребенок, эта мера оценивается невысоко, что может иметь разные причины: как то, что эта мера пока к ним не относится, так и то, что они в принципе не собираются иметь более двоих детей. Это может свидетельствовать о попрежнему существующей силе нормы, согласно которой лучше не иметь более двоих детей, как минимум у существенной части населения. О сохранении этой нормы (среднего желаемого числа детей чуть выше двух при незначительных колебаниях), впервые выявленной еще в советское время и затем неоднократно подтверждавшейся различными исследованиями [Варламова, Носкова, Седова 2006] свидетельствует и сам Доклад о МКП2015 [Доклад... 2016: 10-11]. Аналогична динамика оценок получения земли под строительство дома, хотя они и несколько ниже по абсолютной величине, - характерен рост среднего балла ко второму ребенку и далее. Причем наиболее выражен этот рост у неработающих, возможно, в целом более ориентированных на дом и хозяйство и/или более часто являющихся сельскими жителями.

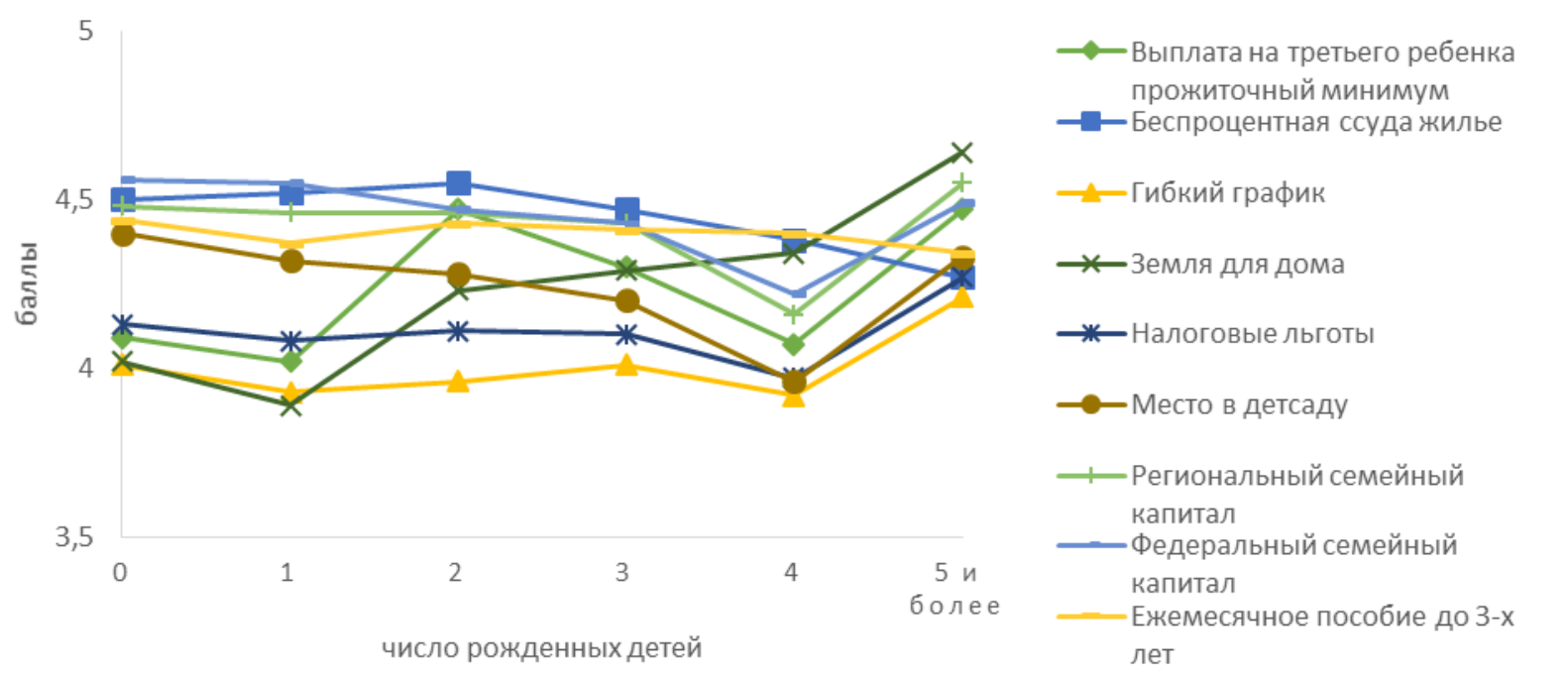

\section{Рисунок 2. Оценка значимости мер поддержки семьи для женщин, не занятых трудовой деятельностью, в зависимости от числа рожденных детей, микроперепись 2015 г., средний балл}

Значимость места в детском саду медленно, но очевидно падает с ростом числа детей у женщины, особенно заметно к четвертому ребенку у неработающих, но она весьма велика 
у пока бездетных и, вероятно, является важным триггером при решении о рождении именно первого ребенка, так как может способствовать иллюзии, что в образе жизни женщины при его или ее рождении мало что изменится.

Довольно низко обеими категориями при любом числе детей оценивается такая мера, как налоговые льготы. Возможно, это связано с тем, что значительная часть населения продолжает работать в сером секторе экономики, для которого такая мера не очень важна. С другой стороны, эта мера людям может быть просто непонятна в отличие от прямых выплат, предполагаемых другими вариантами.

Ежемесячное пособие на ребенка до трех лет (продление оплачиваемого отпуска по уходу за ним до этого момента) выходит на практически лидирующие позиции к тому моменту, когда у матери появляется четверо детей, особенно явно у неработающих, хотя оценивается достаточно высоко и теми, у кого детей меньше или даже нет совсем. Возможно, это связано с более низким уровнем жизни семей с относительно большим количеством детей, а также с тем, что остальные «денежные» меры к этому моменту уже «освоены».

\section{Различия в оценках предлагаемых мер семейной политики в зависимости от уровня образования}

Следующее направление анализа - различия между оценками предлагаемых мер женщинами с различным числом рожденных детей в зависимости от их уровня образования (рисунки 3-8).

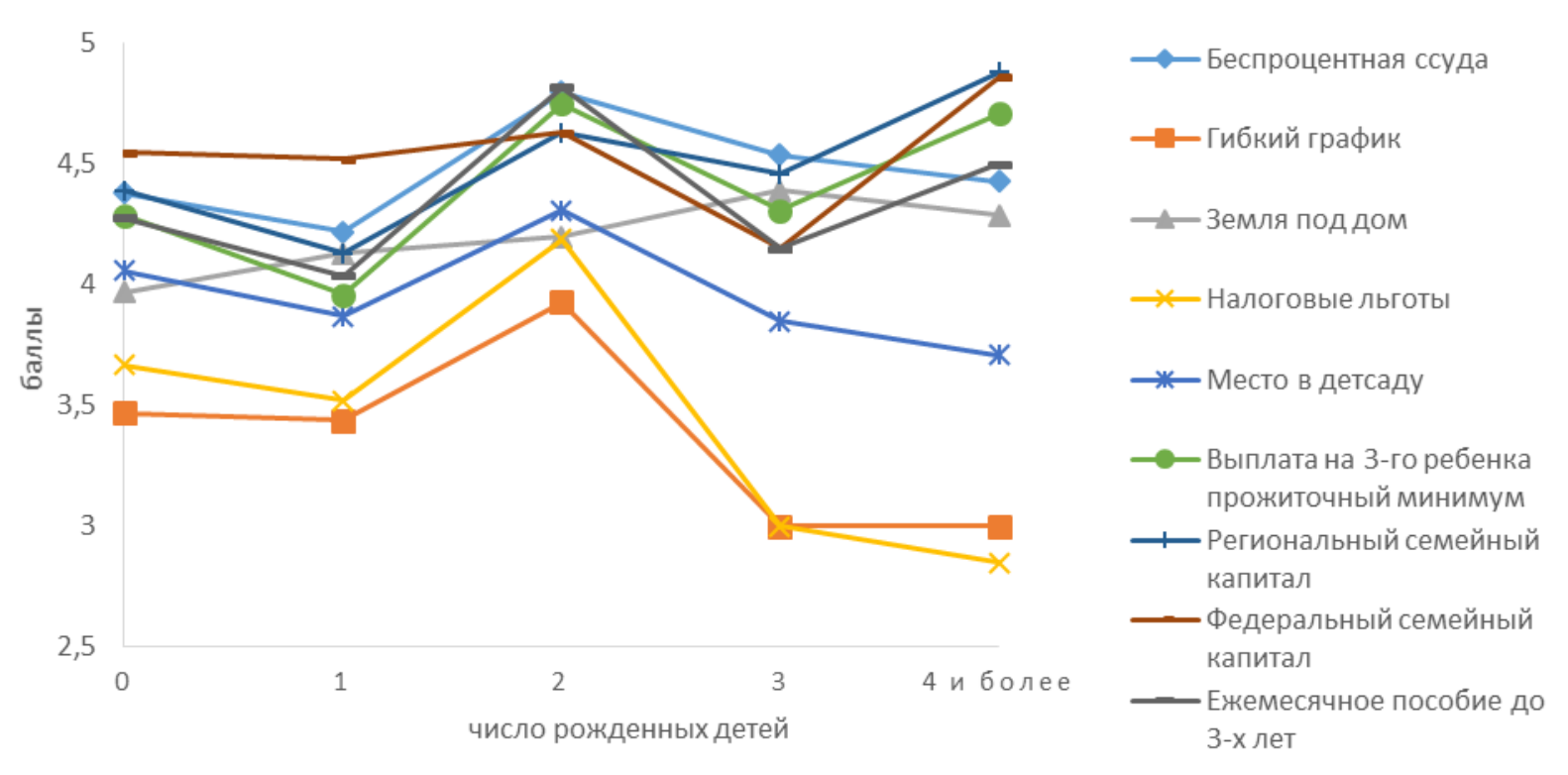

Рисунок 3. Оценка значимости мер поддержки семьи для женщин с начальным образованием в зависимости от числа рожденных детей, микроперепись 2015 г., средний балл

Для женщин с начальным и основным общим образованием (9 классов средней школы и менее) характерна низкая оценка гибкого графика работы, особенно при наличии троих и более детей. Не исключено, что это связано именно с их негативным жизненным 
опытом в этой области - работа по гибкому графику может быть вынужденной и ассоциироваться с частичной безработицей.

Федеральный и региональный капиталы оцениваются в этих образовательных категориях наиболее высоко бездетными и однодетными женщинами, к четвертому ребенку оценка значимости опять растет, нельзя исключить, что в связи с тем, что женщины надеются получить эти выплаты еще раз.

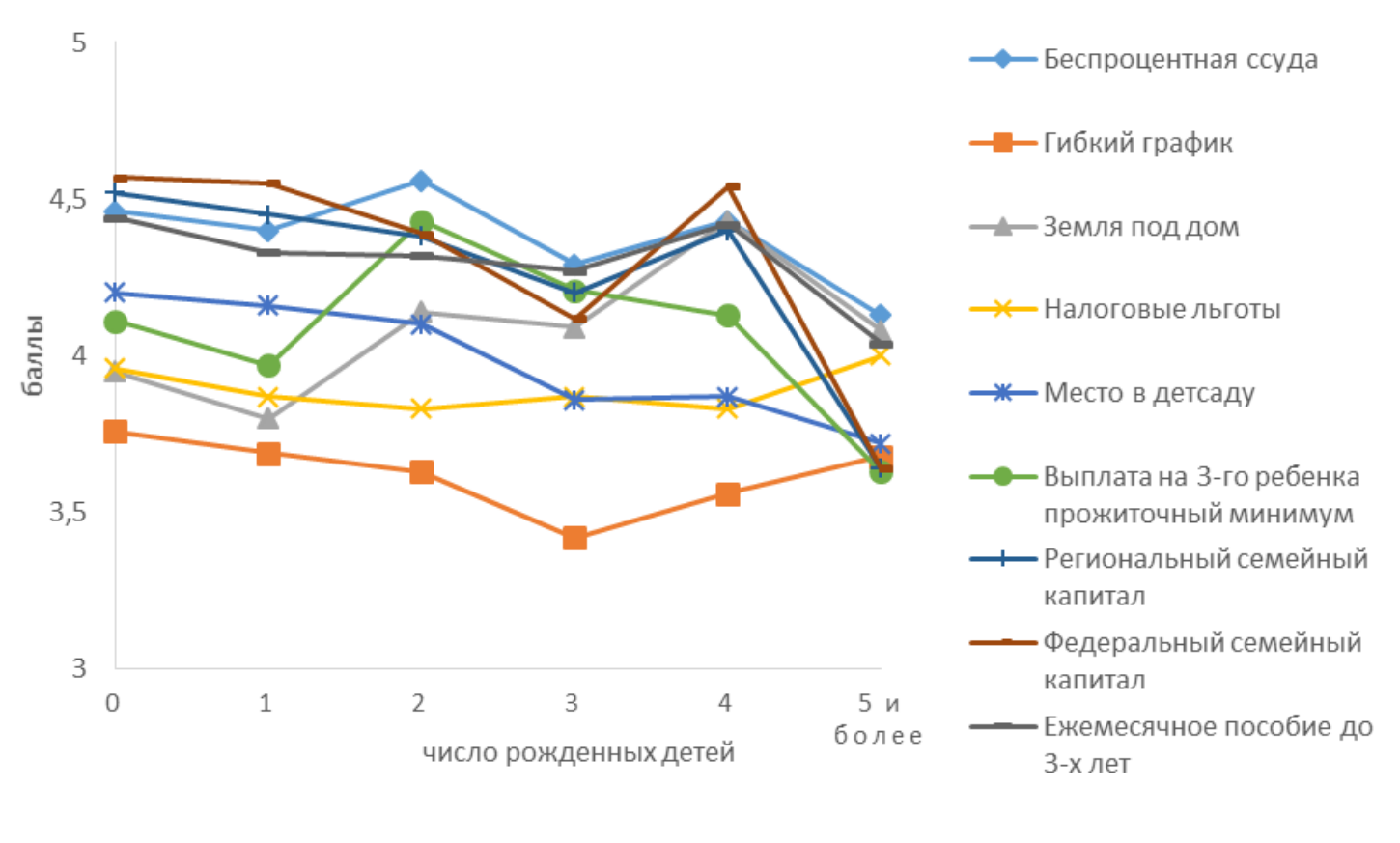

\section{Рисунок 4. Оценка значимости мер поддержки семьи для женщин с основным общим образованием в зависимости от числа рожденных детей, микроперепись 2015 г., средний балл}

Интересны в этих образовательных категориях группы матерей двоих и троих детей. Ко второму ребенку заметно вырастают значение беспроцентной ссуды и ежемесячной выплаты в размере прожиточного минимума, для женщин с начальным образованием - еще и продленного оплачиваемого отпуска по уходу, с основным общим образованием - земли под строительство дома. К третьему ребенку значение всех выплат падает, что может означать, что для этой образовательной группы нормативным (или иным, но не измеряемым в категориях предлагаемых к оценке мер) барьером является рождение не третьего, а четвертого ребенка. Место в детском саду имеет для этих двух образовательных категорий женщин примерно так же мало значения, как налоговые льготы, но все же опережает по значимости гибкий график. 


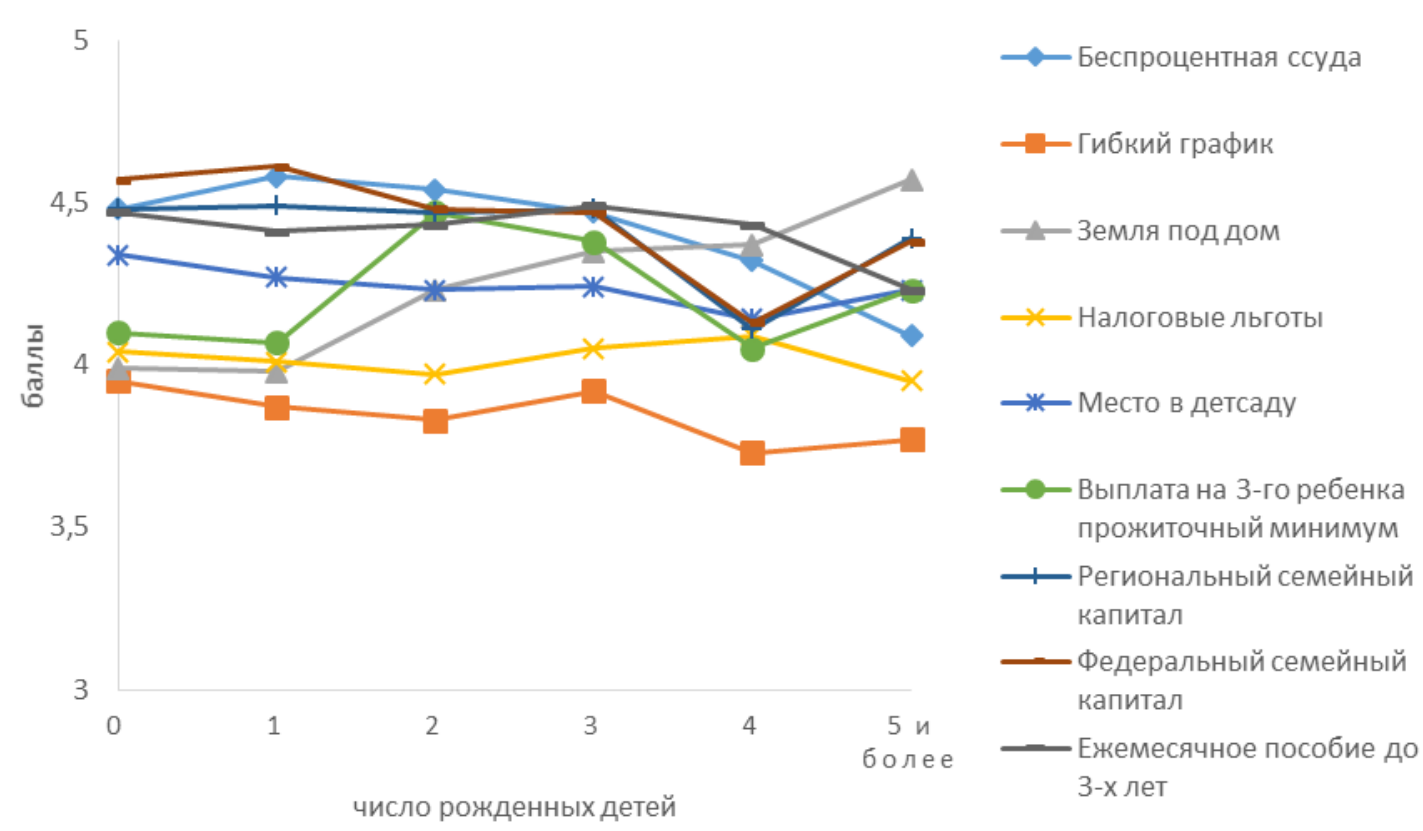

Рисунок 5. Оценка значимости мер поддержки семьи для женщин со средним общим образованием в зависимости от числа рожденных детей, микроперепись 2015 г., средний балл

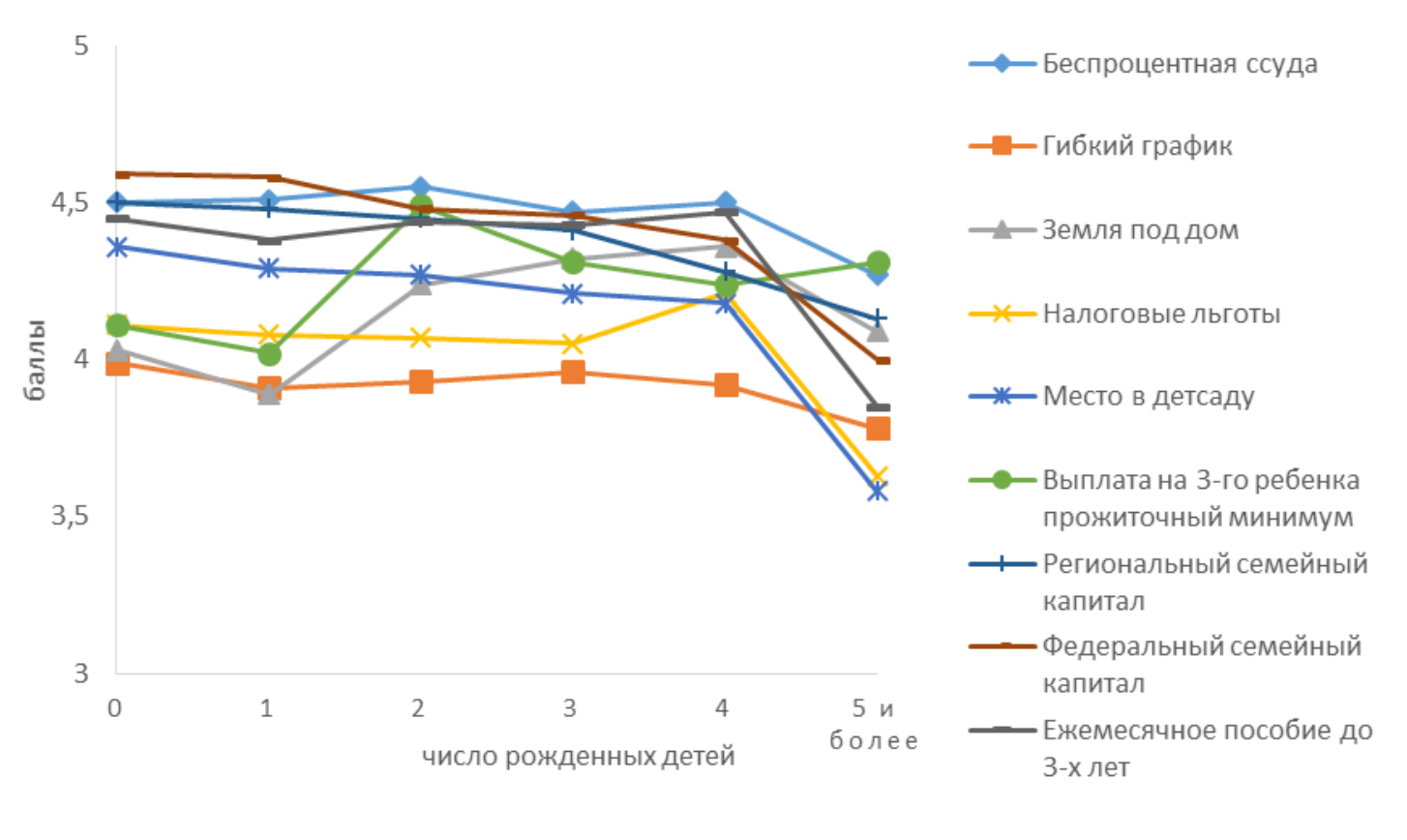

\section{Рисунок 6. Оценка значимости мер поддержки семьи для женщин со средним профессиональным образованием в зависимости от числа рожденных детей, микроперепись 2015 г., средний балл}

Женщины со средним общим (законченная средняя школа) и средним профессиональным образованием также наиболее высоко оценивают федеральный семейный капитал, пока у них нет детей или 1 ребенок, и наиболее низко - гибкий график работы, причем несколько ниже в ситуации, когда у них более троих детей, видимо, потому, что это физически трудно, а экономически не всегда оправдано. Ко второму уже 
рожденному ребенку особенно заметно растет в обеих категориях значение ежемесячных выплат на третьего в размере прожиточного минимума и тоже довольно заметно выделения земли под строительство дома. Лидирует, однако, у матерей двоих и троих детей как в этих, так и в двух категориях с более низким уровнем образования, беспроцентная ссуда на приобретение жилья по социальной норме, видимо, более непосредственно адресованная к одной из наиболее острых проблем семей (жилищной), чем семейный капитал.
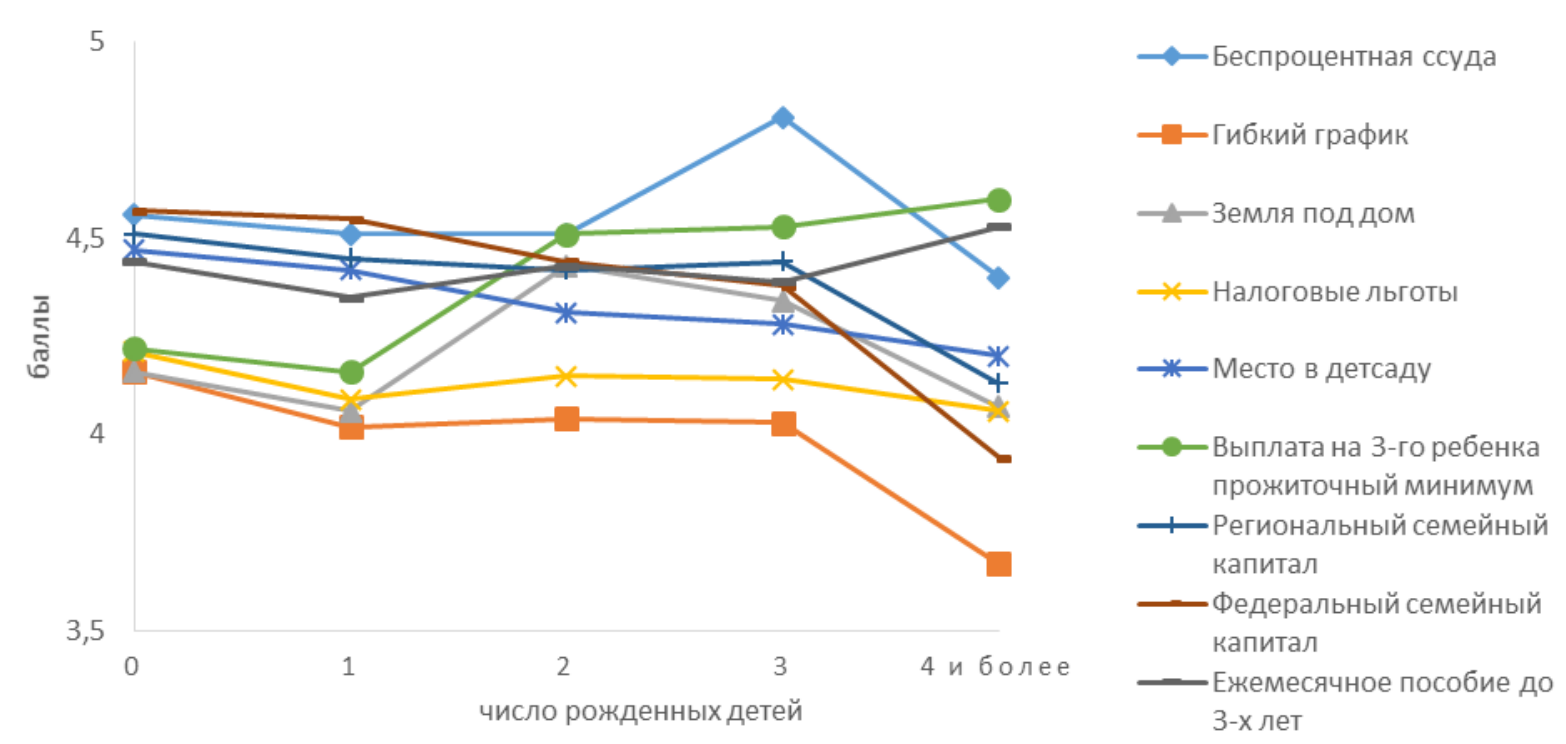

Рисунок 7. Оценка значимости мер поддержки семьи для женщин с незаконченным высшим образованием в зависимости от числа рожденных детей, микроперепись 2015, г., средний балл

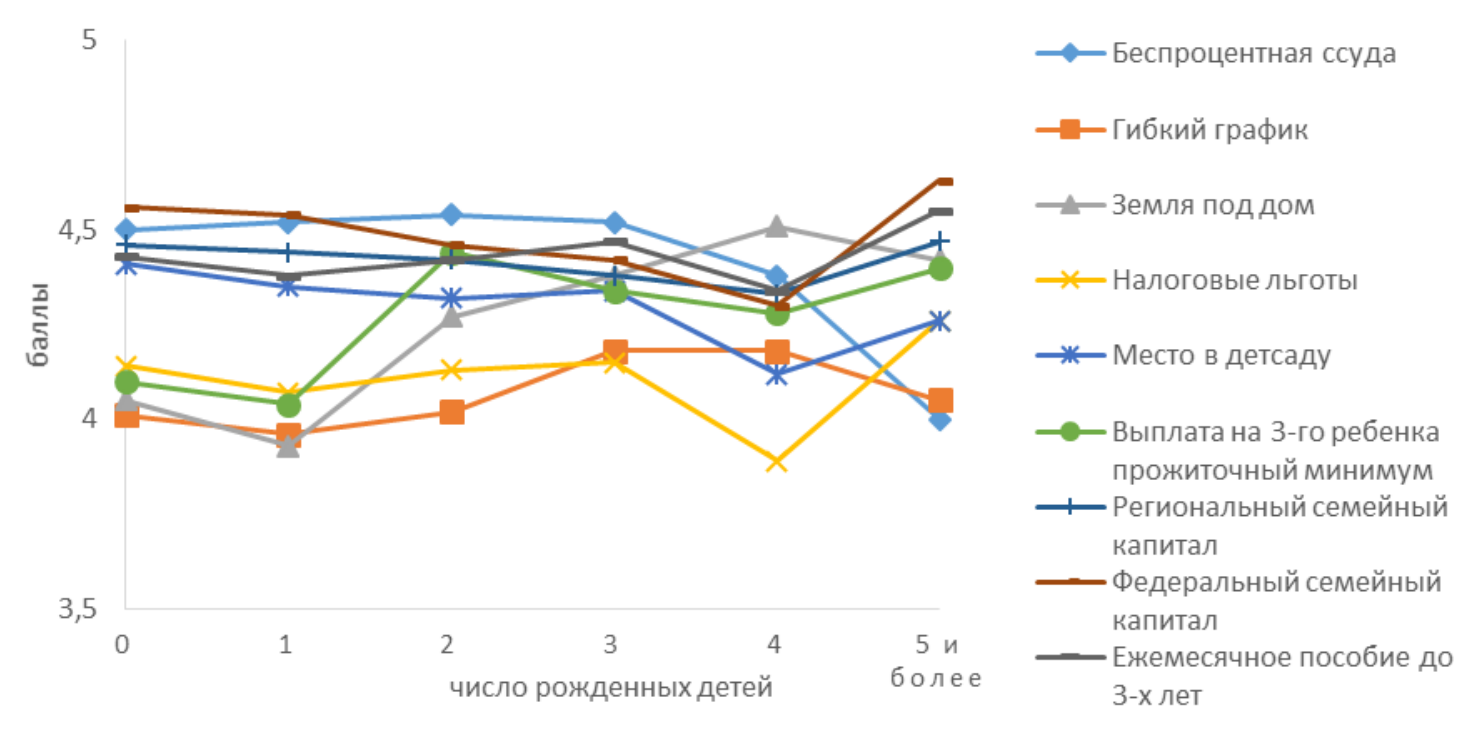

Рисунок 8. Оценка значимости мер поддержки семьи для женщин с высшим образованием в зависимости от числа рожденных детей, микроперепись 2015 г., средний балл 
Гибкий график и налоговые льготы по-прежнему наименее важны, а вот значение места в детском саду уже гораздо выше, чем у менее образованных категорий, но медленно падает с увеличением числа детей у женщины. Продление отпуска по уходу с ежемесячными выплатами - в ряду наиболее важных мер, и начинает лидировать на четвертом ребенке, особенно заметно при среднем общем образовании.

Среди женщин с незаконченным высшим и высшим образованием беспроцентная ссуда на приобретение жилья лидирует еще более заметно все в тех же категориях матерей двоих и троих детей. При законченном высшем образовании и наличии четверых детей на первое место выходит земля под строительство дома. Вообще четверо детей и высшее образование - это довольно интересная, особенная категория, здесь оказываются наименее важны налоговые льготы, даже менее, чем гибкий график и место в детском саду. Складывается образ женщины, осознанно выбравшей «традиционную» жизнь, где дети и дом - ее место в жизни, а работа и все касающиеся ее соображения - прерогатива мужа. При этом хочется именно иметь дом, а не квартиру по беспроцентной ссуде.

Выплаты на третьего ребенка в размере прожиточного минимума продолжают иметь большое значение для женщин с незаконченным высшим образованием при наличии у них более одного ребенка, у женщин с высшим образованием их значение также резко возрастает при переходе от одного ребенка к двоим (как и значение земли под дом: при этом же переходе оно возрастает у обеих категорий).

Заметно падение при переходе от 0 детей к одному ребенку в обеих высших образовательных категориях значения гибкого графика, земли под дом, выплат на третьего ребенка в размере прожиточного минимума и налоговых льгот, при высшем образовании также места в детском саду, хотя оно остается важным, при незаконченном высшем продленного оплачиваемого отпуска по уходу. Все это может свидетельствовать о существовании именно при этих уровнях образования группы женщин, которые все-таки рассматривают как норму именно для «таких, как я» наличие только одного ребенка, хотя их репродуктивные желания могут быть и выше.

При принятии решения о рождении первого ребенка в этих двух группах женщин место в детском саду очевидно входит в группу лидеров, наряду с федеральным семейным капиталом, беспроцентной ссудой на жилье, продлением оплачиваемого отпуска по уходу до трех лет и региональным семейным капиталом. То есть, вероятно, женщины с максимальным человеческим капиталом хотели бы иметь выбор между длительным отпуском, проводимым с ребенком, и ранним выходом на работу при том, чтобы и то, и другое поддерживалось государством.

\section{Различия в оценках мер семейной политики муючинами в зависимости от уровня образования и трудового статуса}

В отличие от информации о женщинах микроперепись 2015 г. не дает очевидного распределения мужчин репродуктивного возраста по числу воспитываемых ими детей, поэтому оценка значимости мер политики для мужчин была произведена только в зависимости от уровня их образования и трудового статуса (рисунки 9, 10). 
Можно видеть, что федеральный семейный капитал лидирует только у мужчин с основным общим образованием (9 классов). Для мужчин с начальным образованием всетаки важнее беспроцентная ссуда на приобретение жилья, как и для всех уровней образования выше 9 классов. Федеральный семейный капитал занимает в «рейтинге» всех групп мужчин, кроме окончивших 9 классов, второе место, за ним следует региональный семейный капитал. Следующая по важности мера для мужчин с незаконченным высшим и высшим образованием - место в детском саду, для остальных - продленный оплачиваемый отпуск по уходу до трех лет (у мужчин со средним профессиональным образованием эти две меры находятся на одном уровне). Земля под строительство дома имеет высокое значение для таких весьма разных категорий, как мужчины с начальным и с незаконченным высшим образованием. Налоговые льготы и выплата пособия в размере прожиточного минимума на третьего ребенка - следующие по значимости, причем для мужчин с начальным образованием налоговые льготы важны в гораздо меньшей степени, видимо, потому, что эти мужчины сравнительно чаще заняты в сером секторе экономики. Для мужчин с более высоким уровнем образования налоговые льготы несколько важнее (и важнее, чем для большинства женщин), возможно, потому, что именно они чаще работают официально и разбираются в вопросе. Традиционно низшую позицию занимает гибкий график, в данном случае почти наверняка потому, что он минимизирует и заработок. Вообще в целом значимость всех мер по неочевидным для автора причинам сравнительно важнее для мужчин с незаконченным высшим образованием.

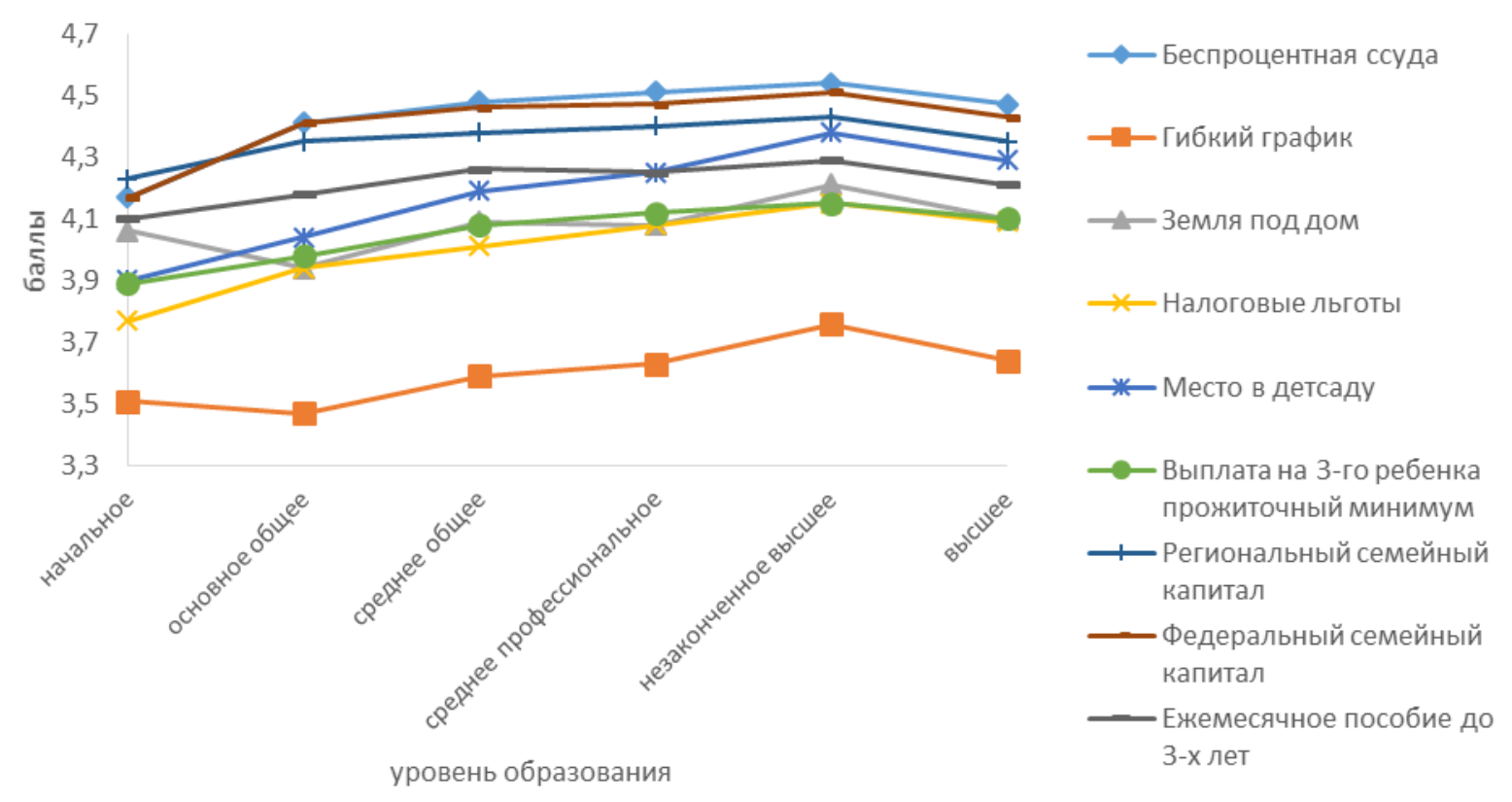

\section{Рисунок 9. Оценка значимости мер поддержки семьи мужчинами с различным уровнем образования, микроперепись 2015 г., средний балл}

Для мужчин, у которых отсутствует формальная трудовая деятельность, почти все меры семейной поддержки, за исключением продленного оплачиваемого отпуска по уходу за ребенком, важнее, чем для тех, кто работает официально (возможно, потому, что они не вполне уверены в своей способности прокормить столь длительно неработающую женщину, пусть и получающую небольшое пособие). Земля под строительство дома 
одинаково важна для обеих категорий по трудовому статусу. При этом различия в оценках между двумя категориями очень невелики, лидирует беспроцентная ссуда на покупку жилья (заметно важнее для формально неработающих), за ней следуют федеральный маткапитал, региональный семейный капитал и место в детском саду (опять существенно важнее для формально неработающих). Несколько менее важны налоговые льготы (для неработающих особенно, то есть это, возможно, могло бы побудить кого-то «выйти из тени»), ежемесячная выплата на третьего ребенка и земля под строительство дома. Наименее важен, с большим отрывом, гибкий график, почти одинаково для обеих сравниваемых категорий.

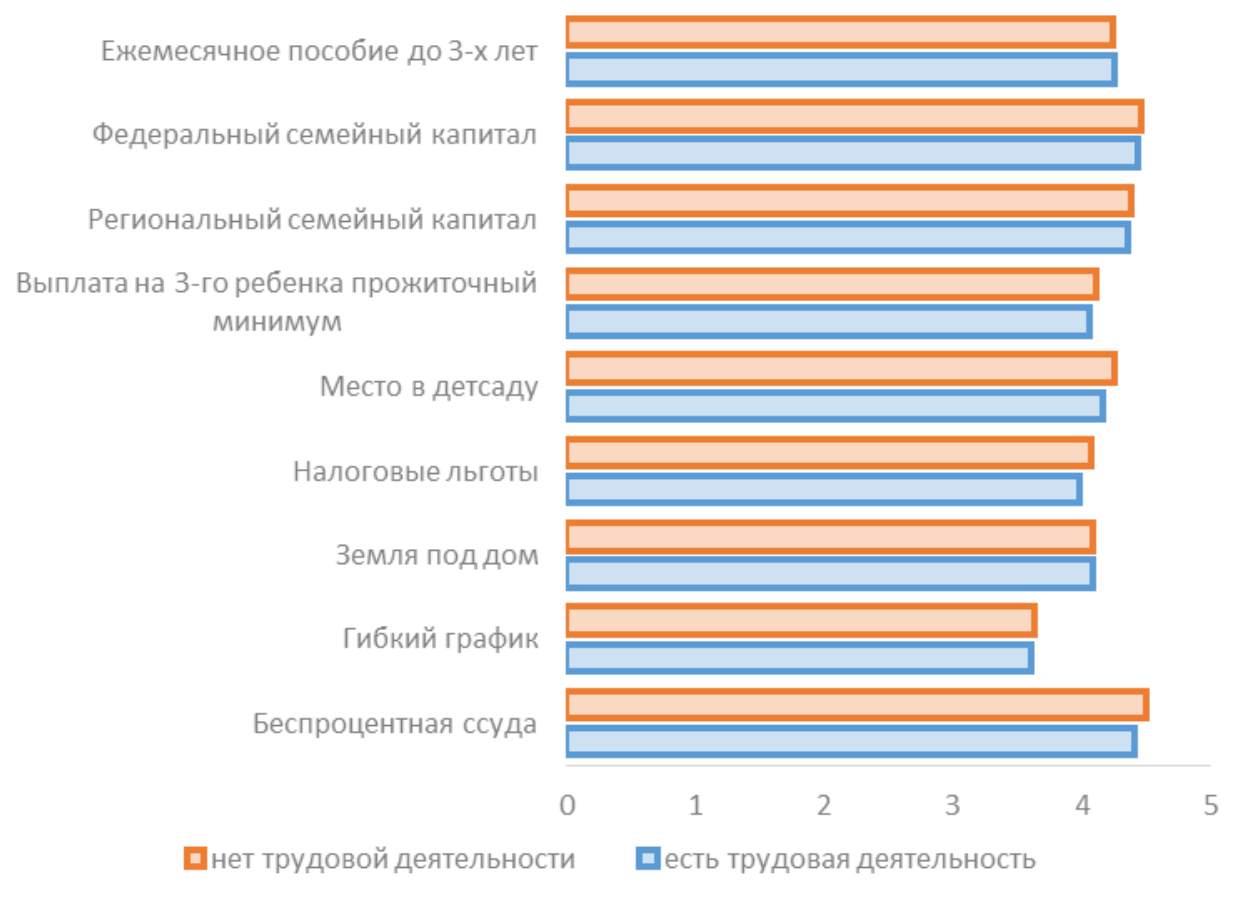

\section{Рисунок 10. Оценка значимости мер поддержки семьи мужчинами в зависимости от наличия трудовой деятельности, микроперепись 2015 г., средний балл}

\section{Различия в оценках предлагаемых мер семейной политики в зависимости от возраста}

Если посмотреть распределение оценок по возрасту отдельно для мужчин и женщин, увидим, что для женщин в целом характерна наиболее высокая оценка беспроцентной ссуды на жилье в возрасте 30-39 лет и федерального материнского капитала в остальных репродуктивных возрастах (рисунок 11). Более молодые женщины оценивают все меры наиболее высоко по сравнению со всеми категориями в возрасте 30 лет и старше. Падение значения регионального материнского капитала происходит к возрасту 35 лет и далее не возрастает. Наиболее высоко оценивают продление оплачиваемого отпуска по уходу за ребенком до трех лет самые молодые женщины (18-24 года), к 25-29 годам его значение падает, наиболее низко оно у женщин 35 лет и старше. С возрастом также падает значение места в детском саду, в целом это средняя по привлекательности мера, если смотреть на возрастном распределении. Наименее привлекательны гибкий график, земля под строительство дома и налоговые льготы (последние относительно более важны для женщин 
40-44 лет). Ежемесячная выплата на третьего ребенка в размере прожиточного минимума также относится к мерам средней степени привлекательности.

Возможно, такие оценки отчасти можно соотнести с оптимизмом, свойственным молодости, но интересно внимание молодежи ко всем формам именно денежных выплат, включая даже и выплаты в течение отпуска по уходу за ребенком, по сравнению с косвенными мерами, которые не так легко представить себе в «живых» деньгах.

Если теперь рассмотреть городских и сельских женщин отдельно (рисунки 12, 13), то видим, что у горожанок беспроцентная ссуда становится явным лидером во всех возрастах, за исключением группы 40-44 года. Наиболее заметна разница в оценке ссуды и федерального маткапитала в возрасте 30-34 года (не в пользу последнего). Затем идет региональный семейный капитал, затем - ежемесячное пособие в отпуске по уходу за ребенком до трех лет, более привлекательное для молодых женщин. Место в детском саду оценивается так же высоко, как и это пособие, только женщинами 30 лет и старше. Средними по привлекательности остаются ежемесячное пособие на третьего ребенка и налоговые льготы, а земля под строительство дома для женщин старше 35 лет даже менее привлекательна, чем гибкий график.

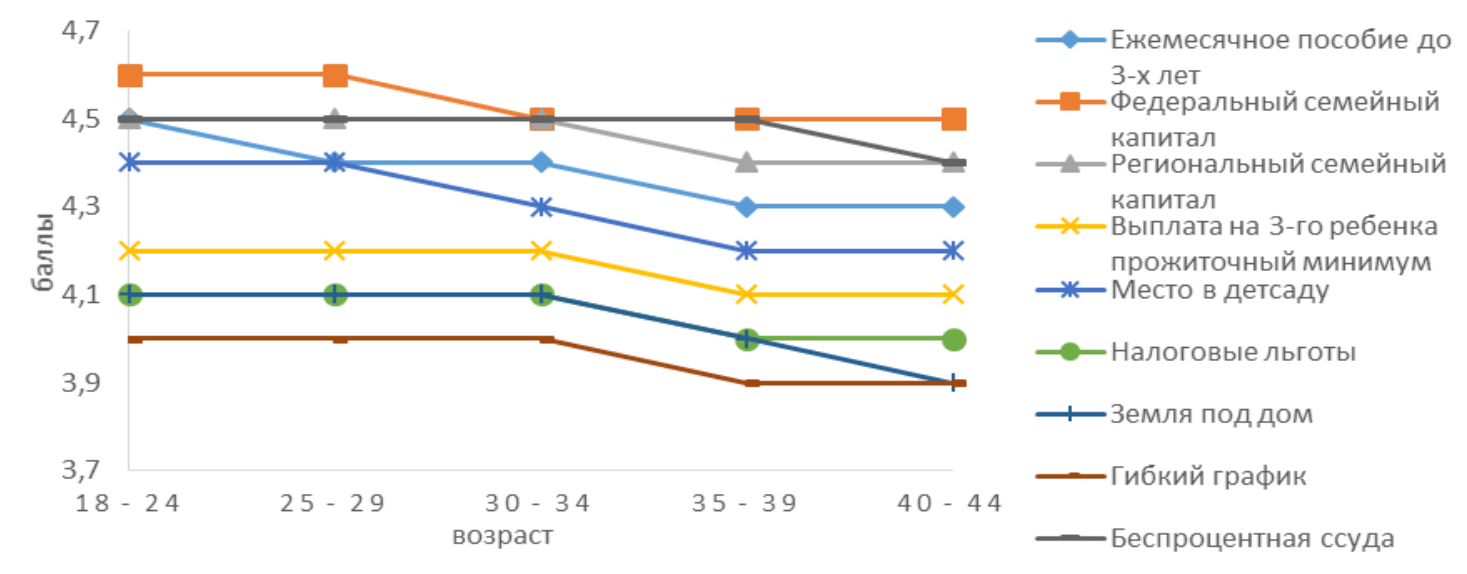

Рисунок 11. Оценка значимости мер поддержки семьи женщинами в зависимости от возраста, микроперепись 2015 г., средний балл

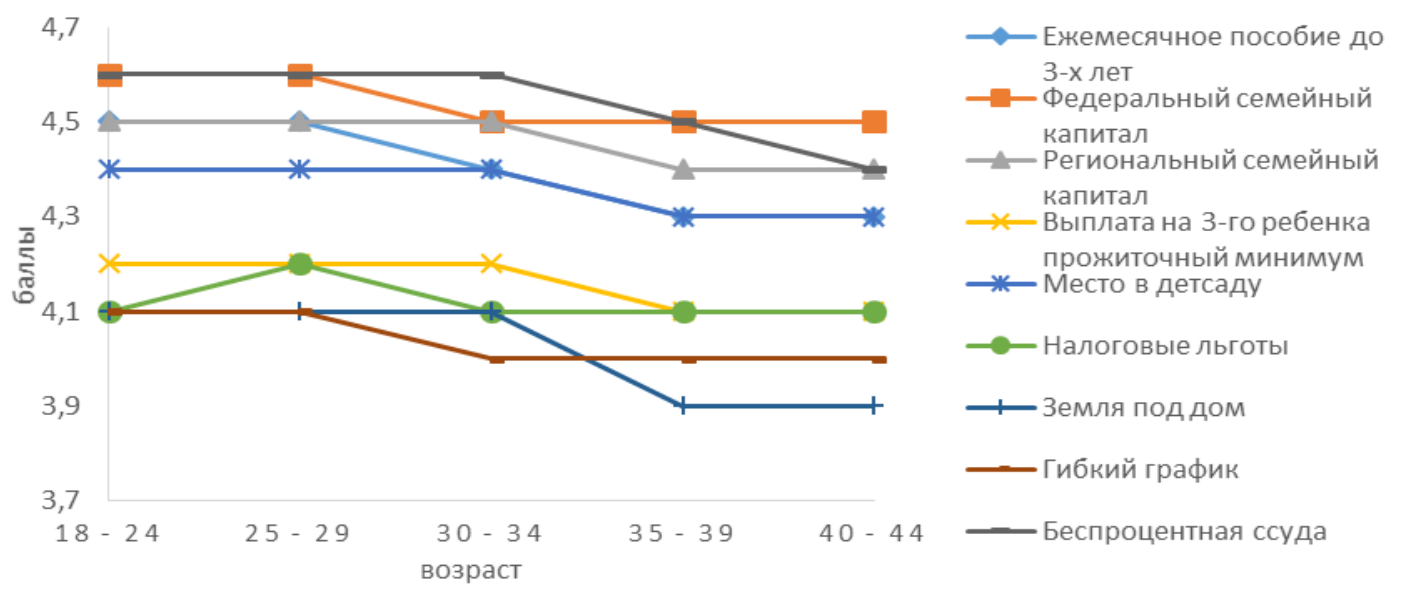

Рисунок 12. Оценка значимости мер поддержки семьи женщинами в зависимости от возраста, городские поселения, микроперепись 2015 г., средний балл 
Картина у сельских жительниц несколько отличается. Гибкий график работы здесь является аутсайдером с особенно большим отрывом, видимо, потому, что эта мера не релевантна современному образу жизни большинства сельчанок. Беспроцентная ссуда на жилье остается одним из лидеров во всех возрастных группах, только у 18-24-летних ее опережает федеральный маткапитал, а у 40-44-летних - региональный.

Ежемесячное пособие для всех детей до трех лет - уверенный член лидирующей группы мер во всех возрастах.

Остальные меры - в группе средних по привлекательности, причем с 25-29 лет возрастает значение ежемесячной выплаты на третьего ребенка, а значение места в детском саду после этого возраста падает. Удивительно, что с этого же возраста падает и значимость выделения земли под строительство дома, и в целом оцениваемое достаточно низко. Возможно, это связано с тем, что люди начинают понимать, что одной земли недостаточно и сам процесс строительства долог и потребует вложения больших денег. Наименее привлекательны в этой «средней» группе примерно в равной степени для всех возрастов налоговые льготы.

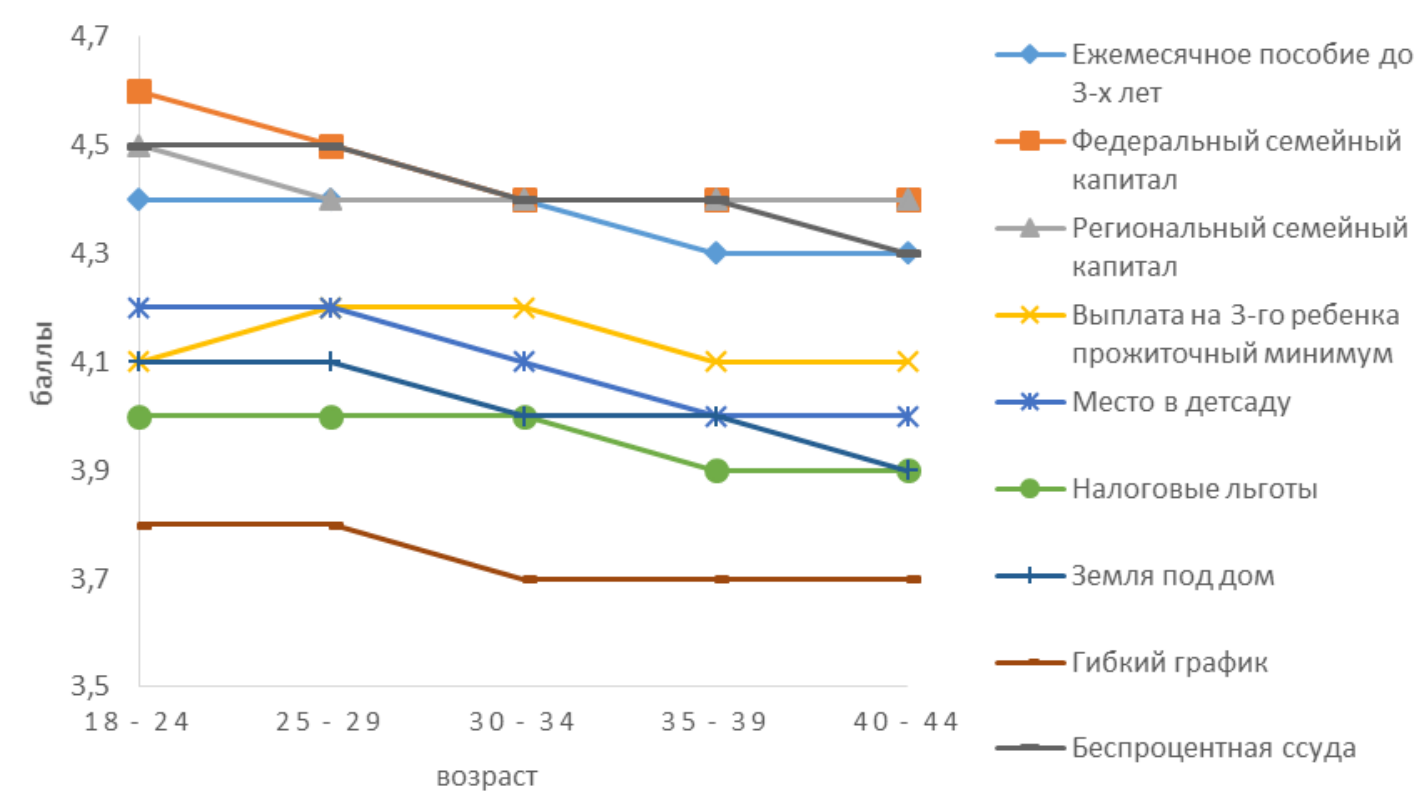

\section{Рисунок 13. Оценка значимости мер поддержки семьи женщинами в зависимости от возраста, сельские поселения, микроперепись 2015 г., средний балл}

Распределение оценок у мужчин несколько отличается (рисунки 14-16). Во-первых, по России в целом гибкий график они оценивают еще более низко, чем женщины, что вполне объяснимо различиями в существующих в нашем обществе гендерных ролях и ожиданиях, предполагающих, что основная задача мужчины в семье - обеспечение дохода, а не участие в домашних делах, предполагаемое гибким графиком.

И по России в целом, и особенно по городскому населению, у мужчин всех возрастов в оценках лидирует беспроцентная ссуда на приобретение жилья. У сельских мужчин лидирует она же, за исключением группы старше 49 лет (им больше нравится федеральный 
семейный капитал). Федеральный и региональный семейные капиталы - следующие по привлекательности и в целом, и в городе, и на селе.

Молодые мужчины (до 30 лет) так же, как и молодые женщины, несколько более позитивны в своих оценках всех предлагаемых мер, однако у сельского населения эта тенденция практически не выражена.

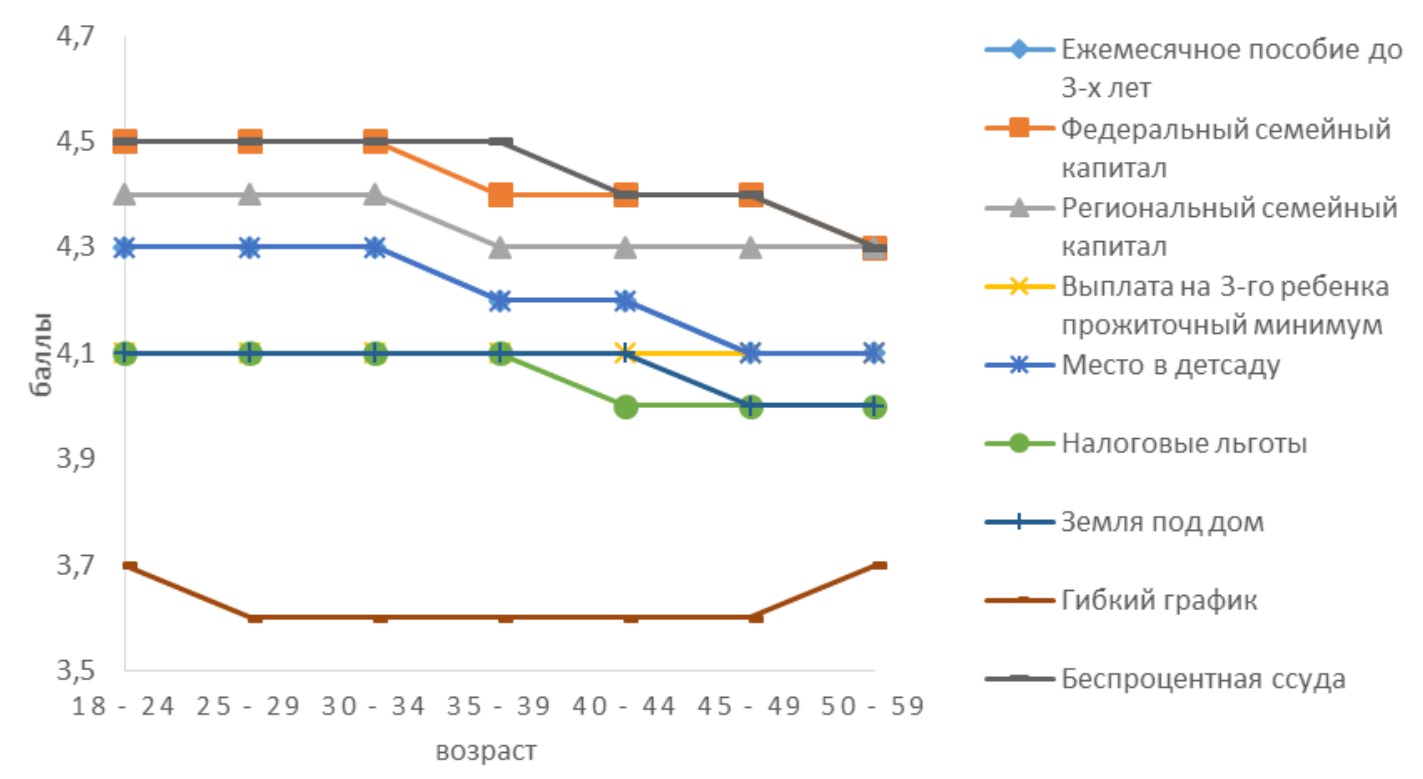

Рисунок 14. Оценка значимости мер поддержки семьи мужчинами в зависимости от возраста, микроперепись 2015 г., средний балл

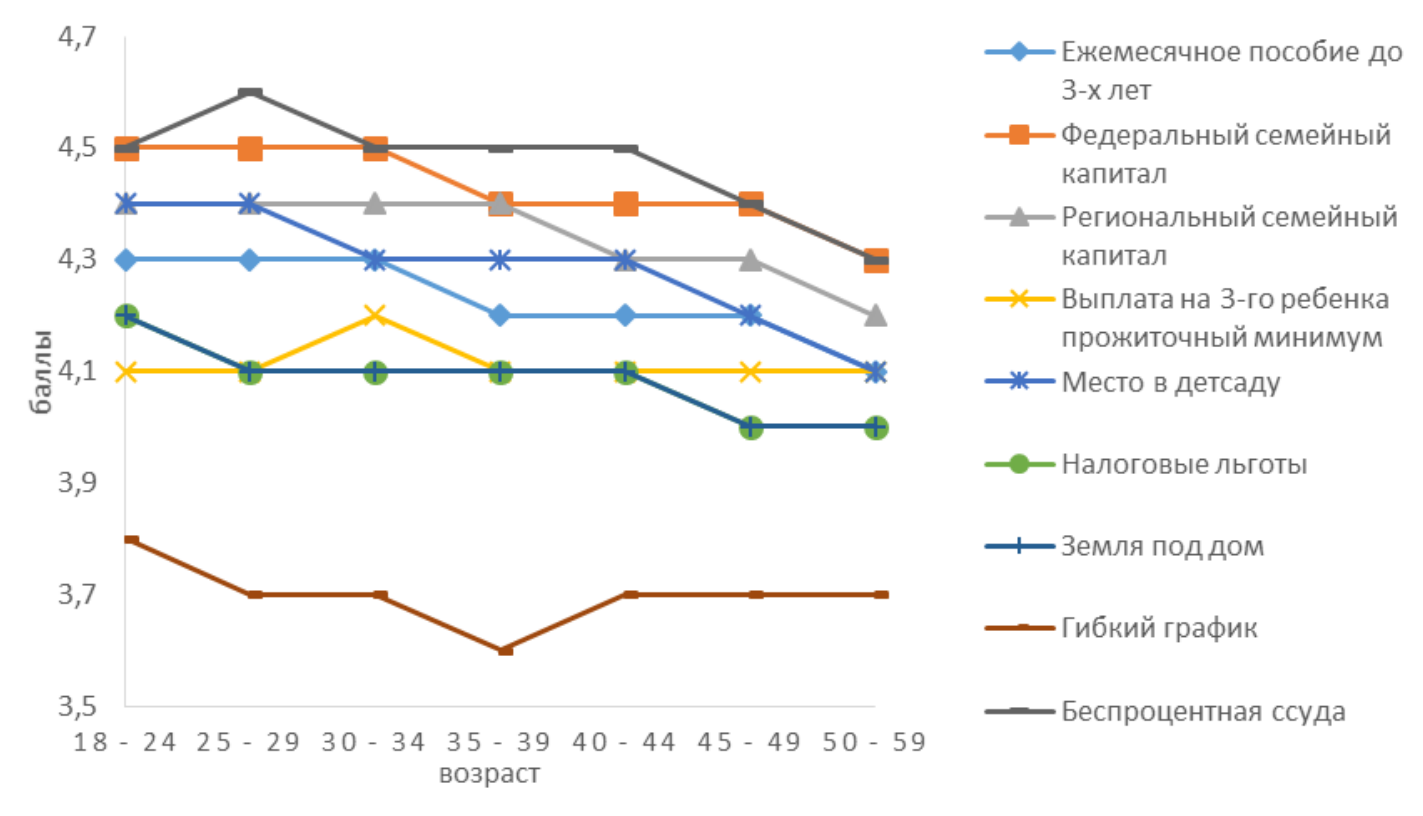

\section{Рисунок 15. Оценка значимости мер поддержки семьи мужчинами в зависимости от возраста, городские поселения, микроперепись 2015 г., средний балл}

Налоговые льготы, земля под строительство дома и ежемесячное пособие на третьего ребенка по России в целом и по городскому населению (которое ожидаемо несколько ниже, чем такое пособие, оценивает землю под строительство дома) 
воспринимаются как относительно непривлекательные меры во всех возрастных группах, однако оцениваются намного выше, чем гибкий график. Место в детском саду и продленный оплачиваемый отпуск по уходу за ребенком до трех лет оцениваются средне и абсолютно идентично для населения России в целом, постепенно снижаясь с увеличением возраста отцов. Горожане, особенно самые молодые, несколько выше оценивают все же место в детском саду. Налоговые льготы особенно низко оценивает возрастная группа 4044 года (по России в целом), а также все сельские мужчины - для них эта мера, видимо, малорелевантна. До 35 лет мужчины на селе несколько выше ценят место в детском саду, в более старших возрастах - предоставление земли под строительство дома. Но оценки этих двух мер очень близки друг к другу, и они средние. Ежемесячное пособие до трех лет на каждого ребенка (продленный отпуск по уходу) сельские мужчины всех возрастов оценивают несколько выше - почти так же высоко, как региональный семейный капитал.

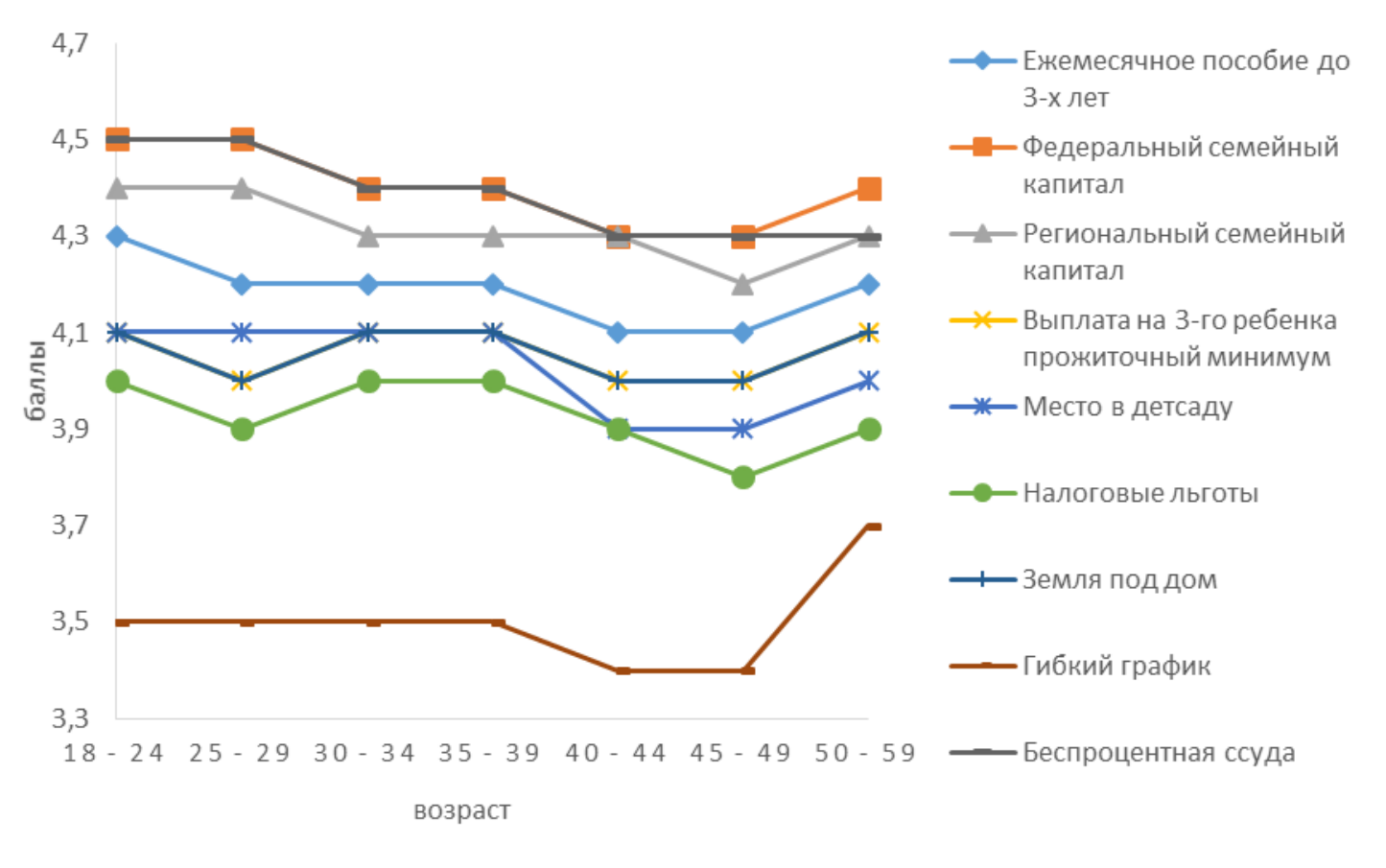

Рисунок 16. Оценка значимости мер поддержки семьи мужчинами в зависимости от возраста, сельские поселения, микроперепись 2015 г., средний балл

\section{Различия в восприятии мер семейной политики в зависимости от числа уже имеющихся и желаемых детей}

Осталось рассмотреть оценки предлагаемых мер семейной политики различными группами мужчин и женщин в зависимости от числа уже имеющихся у них и желаемых ими детей (рисунки 17-21).

Россия в целом без разделения на городское и сельское население: беспроцентная ссуда опять лидирует, причем тем более очевидно, чем больше у женщины детей и чем больше детей она желает иметь. Для тех, у кого пока нет детей, но они хотели бы иметь от одного до троих, более привлекателен федеральный семейный капитал. Земля под строительство дома наименее привлекательна для тех, кто в целом хочет иметь не более двоих детей, и заметно более привлекательна при желании иметь троих и более. Примерно 
одинаково и равно для всех категорий малоинтересны гибкий график и налоговые льготы, хотя первый наименее привлекателен для желающих иметь только одного ребенка, а вторые именно для этой категории несколько более привлекательны. Оценки ежемесячной выплаты на третьего ребенка минимальны у тех, кто хочет не более одного ребенка и не более двоих (и при этом пока имеет меньше, чем хочет), максимальны у тех, кто хочет троих детей и более. Место в детском саду желающие иметь троих и более детей оценивают даже выше, чем те, кто хочет только одного или двоих (а также чем те, кто уже имеет троих и хочет еще больше). Значимость ежемесячной выплаты на каждого ребенка до трех лет (продления отпуска по уходу) высока, особенно у желающих иметь троих и более детей. Примерно на этом же уровне оценивается региональный семейный капитал.

Можно видеть заметное разделение на модели семьи по желаемому числу детей и существенные различия в оценках мер семейной политики представительницами разных типов.

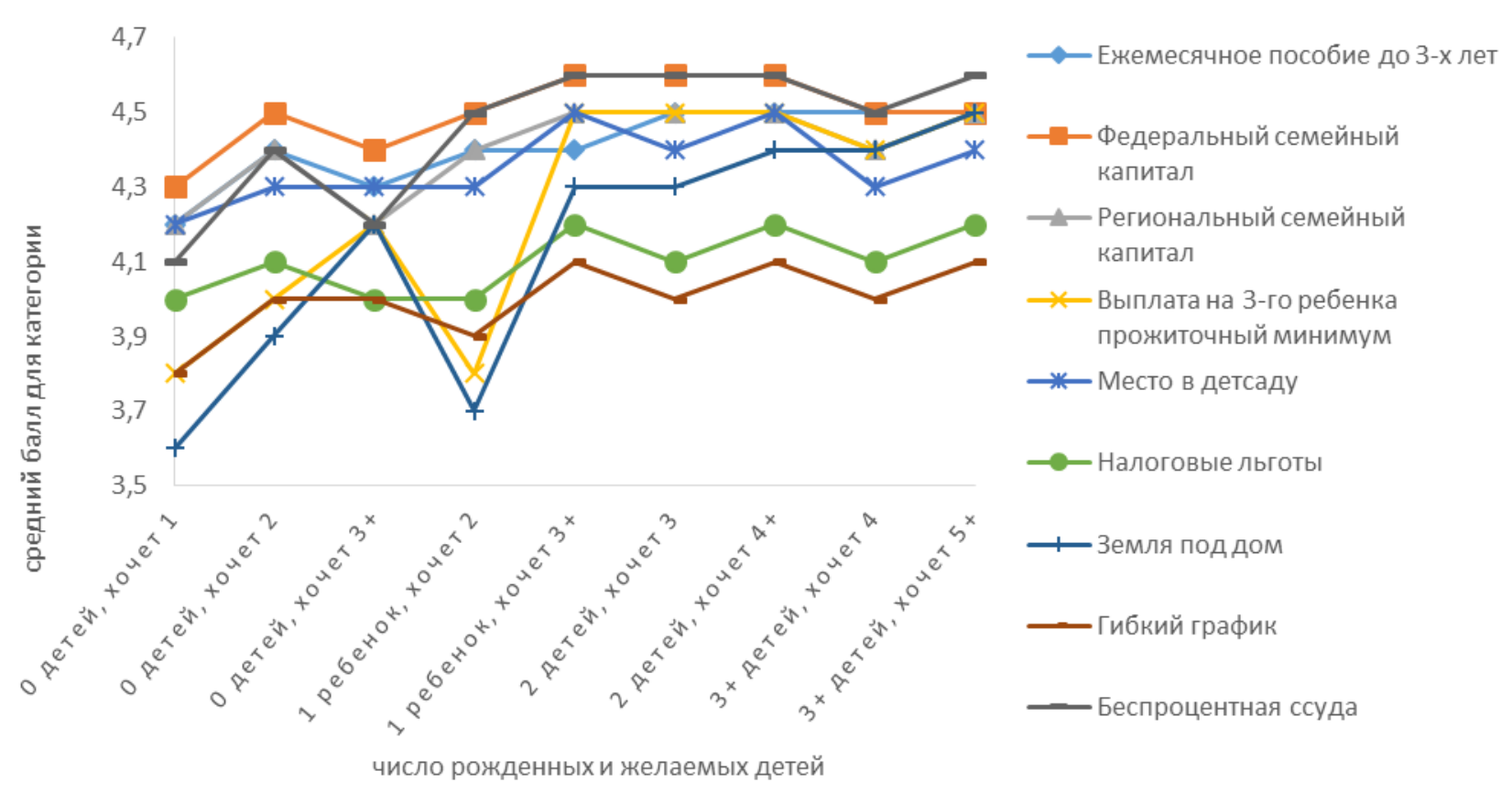

\section{Рисунок 17. Оценка значимости мер поддержки семьи женщинами в зависимости от числа рожденных и числа желаемых детей, микроперепись 2015 г., средний балл}

Если посмотреть отдельно на горожанок и жительниц села, то увидим, что первые практически не отличаются в своих оценках от россиянок в целом: та же характерная низкая оценка мер, направленных на рождение третьего ребенка у тех, кто имеет одного и хотел бы максимум двоих, и одинаково высокая практически всех мер теми, кто пока не имеет детей, но хочет троих.

У жительниц села низкая оценка при наличии одного ребенка и желании только двоих также присутствует, но в несколько более размазанном виде. Размазан и максимум при желании троих, когда пока нет ни одного. Вплоть до ситуации «двое детей, хочет троих» лидирует федеральный семейный капитал, за ним следует (при малом числе имеющихся и желаемых детей) региональный, ссуда на покупку жилья выходит в лидеры, только когда и имеющихся, и желаемых детей уже больше одного. В этот же момент 
начинает лидировать и ежемесячное пособие на каждого ребенка (продленный отпуск по уходу). Чуть менее, но привлекателен для желающих иметь большую семью и мало привлекателен для желающих иметь маленькую вариант с пособием в размере прожиточного минимума на третьего ребенка. Место в детском саду занимает ровные средние позиции, почти параллельно ему, но ниже по привлекательности, налоговые льготы и еще ниже для всех категорий гибкий график.

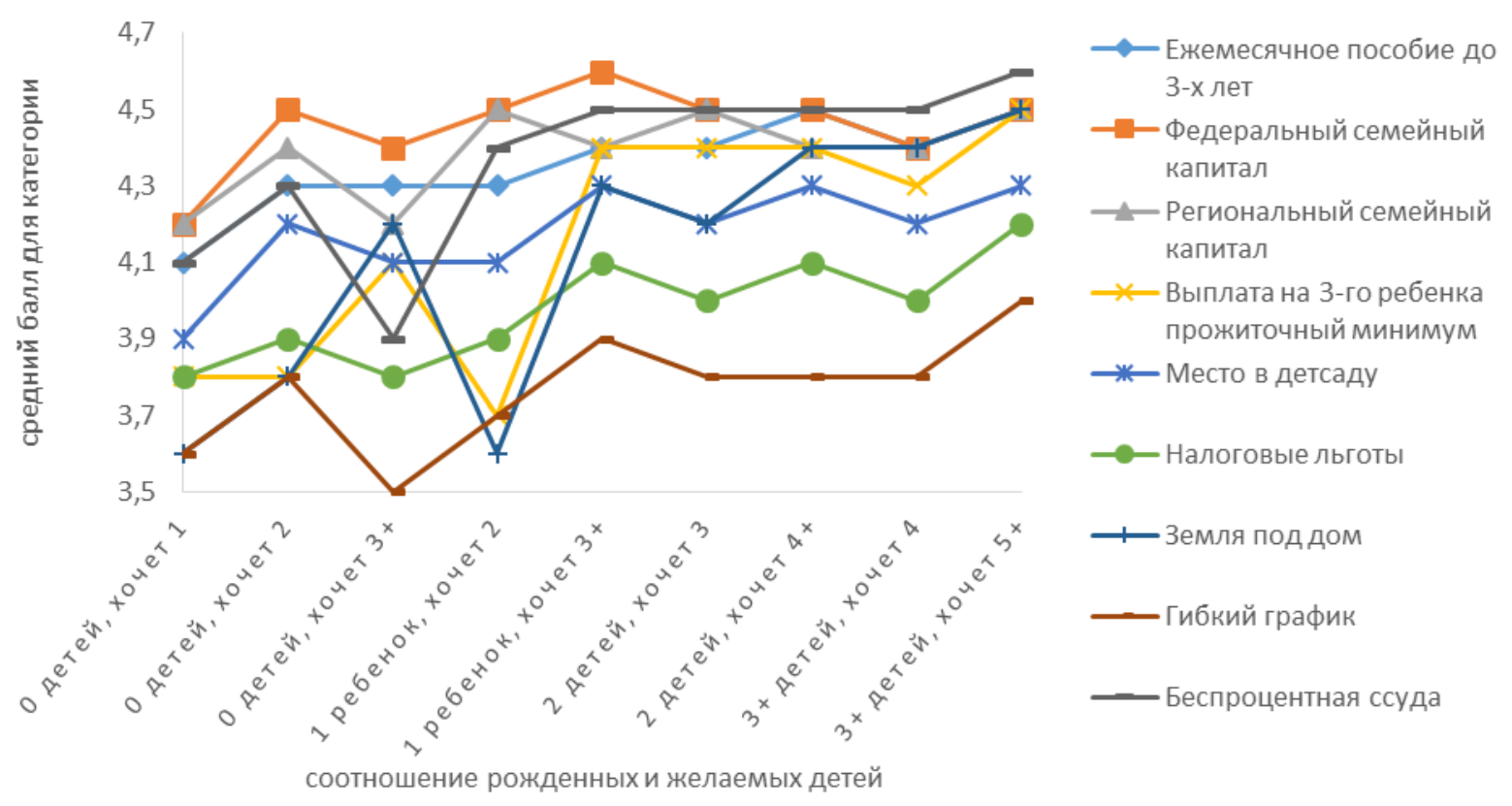

Рисунок 18. Оценка значимости мер поддержки семьи женщинами в зависимости от числа рожденных и желаемых детей, сельские поселения, микроперепись 2015 г., средний балл
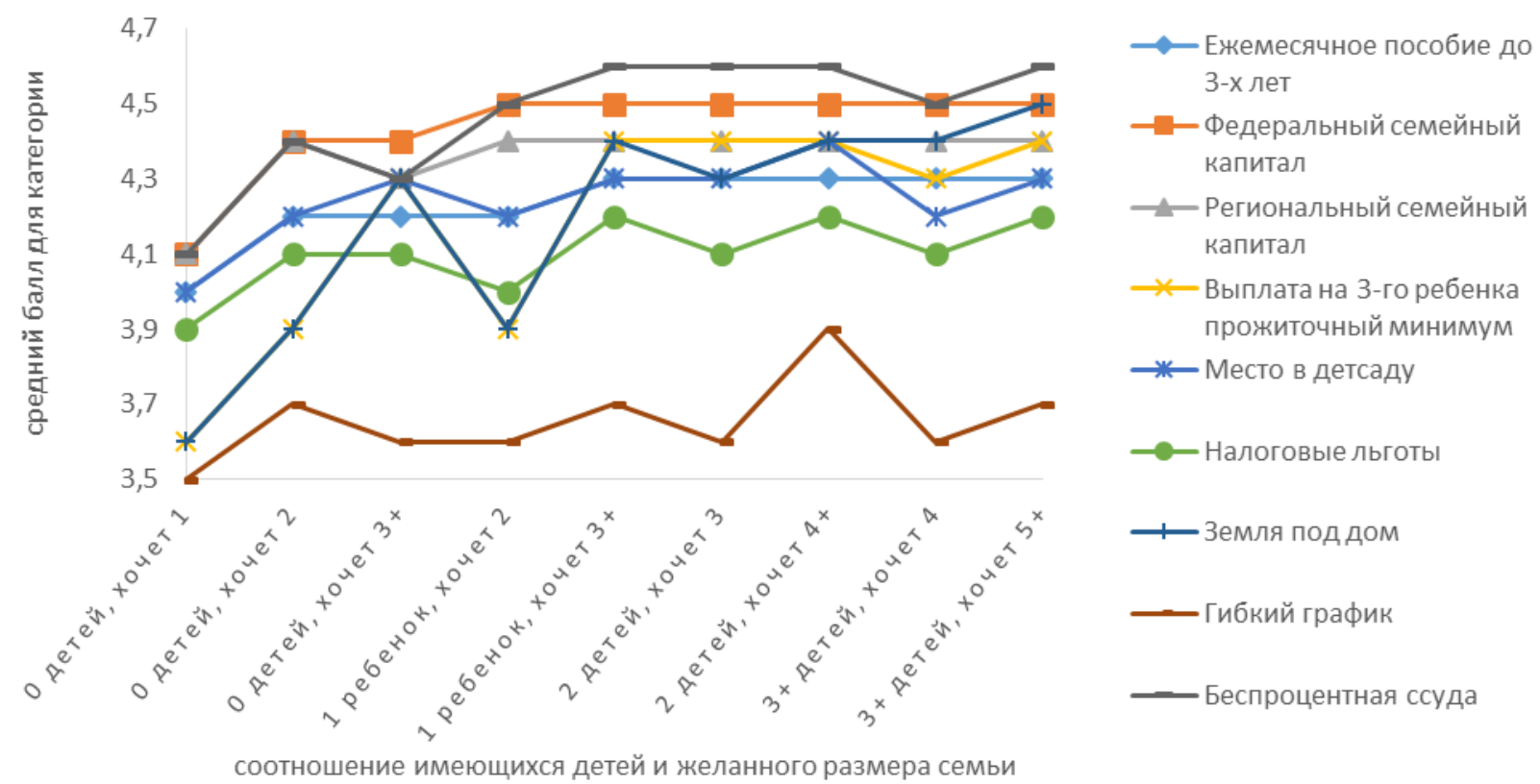

Рисунок 19. Оценка значимости мер поддержки семьи мужчинами в зависимости от числа имеющихся и желаемых детей, микроперепись 2015 г., средний балл 


\section{Посмотрим на распределения у мужчин.}

Россия в целом: беспроцентная ссуда лидирует у всех категорий, кроме тех, у кого нет детей, но они хотят троих (им важнее федеральный семейный капитал). Гибкий график оценивается, как обычно, наиболее низко, но мужчины, у которых двое детей, а хотят они четверых и более, выделяются относительно более высокой оценкой этой меры. Возможно, это аргумент в дискуссиях с партнершей о том, что при увеличении числа детей они будут уделять больше внимания семейным делам. Относительно низко оценивают выделение земли под строительство дома все те, кто не хочет иметь более двоих детей, и высоко остальные. Налоговые льготы - вторые по непривлекательности в среднем, их оценка распределена по категориям примерно равномерно. Довольно высоко все оценивают место в детском саду, ежемесячное пособие для всех до трех лет и региональный семейный капитал. Пособие на третьего ребенка в размере прожиточного минимума значимо для сторонников больших семей. Есть тот же минимум оценок при ситуации «есть один, хочет двоих» и максимум в ситуации «нет детей, хочет троих», но они более размазаны, чем у женщин. Значение всех мер несколько увеличивается у имеющих троих детей и желающих в общей сложности не менее пятерых.

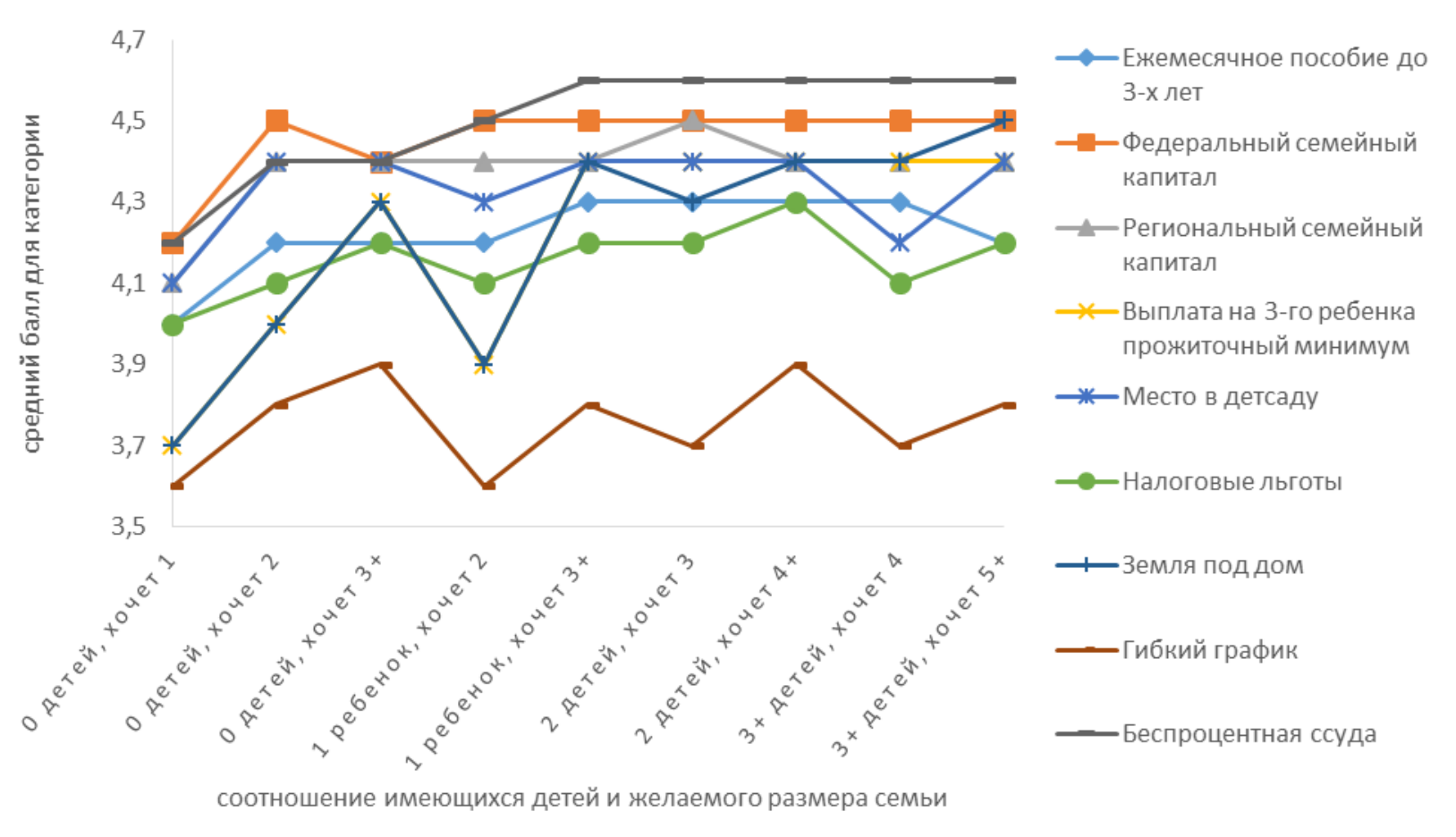

\section{Рисунок 20. Оценка значимости мер поддержки семьи мужчинами в зависимости от числа имеющихся и желаемых детей, городские поселения, микроперепись 2015 г., средний балл}

У городских мужчин позиция «беспроцентная ссуда на покупку жилья» становится лидирующей уже на позиции «один ребенок, хочет двоих», что и понятно в городских условиях. Динамика привлекательности земли под строительство дома такая же, как по России в целом: наблюдается (в относительно размытом виде) минимум оценок у «один ребенок, хочет двоих» и максимум у «нет детей, хочет троих». Гибкий график оценен низко, налоговые льготы тоже, хотя и с заметным отрывом. На втором и третьем местах по 
привлекательности у большинства категорий - федеральный и региональный семейные капиталы. Весьма привлекательно для всех, за исключением тех, у кого уже трое детей и хочется еще больше, место в детском саду, за ним следуют ежемесячное пособие на каждого ребенка до трех лет и земля под дом, а также прожиточный минимум на третьего (для желающих многодетности).

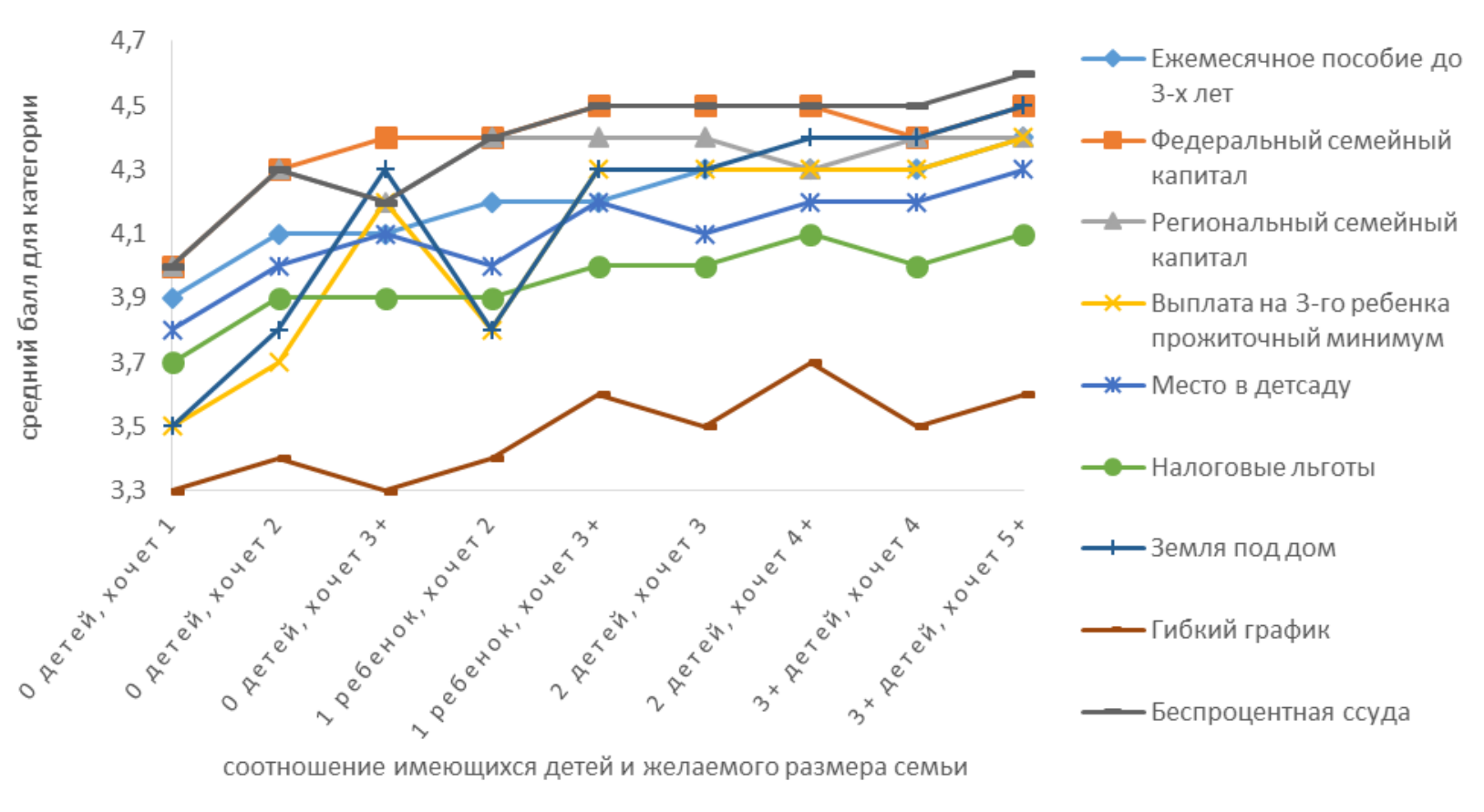

\section{Рисунок 21. Оценка значимости мер поддержки семьи мужчинами в зависимости от числа имеющихся и желаемых детей, сельские поселения, микроперепись 2015 г., средний балл}

Беспроцентная ссуда лидирует и у сельских мужчин: только не имеющие детей, но желающие троих оценивают федеральный семейный капитал выше (региональный капитал, как обычно, следует за федеральным). Эта категория вообще оценивает все меры максимально, а те, у кого один ребенок, а хотят двоих, минимально оценивают землю и пособие на третьего ребенка. Как обычно, очень низка оценка гибкого графика и просто низка - налоговых льгот. Место в детском саду на среднем уровне, пособие до трех лет на всех детей на несколько более высоком. Желающие многодетности высоко ценят землю и пособие на третьего ребенка в размере прожиточного минимума.

\section{ЗАКЛЮЧЕНИЕ}

В целом все наши гипотезы подтвердились. Для всех групп населения характерны ожидания монетарных форм помощи, в то же время наиболее молодые и высокообразованные респонденты, в особенности женщины, высоко оценивают сервисные меры, связанные, прежде всего, с услугами детского сада, при этом часто ориентируясь на рождение только одного ребенка. Однако получились и некоторые неожиданные результаты. А именно, какое бы направление анализа мы ни выбирали, можем видеть, что лидирует беспроцентная ссуда на приобретение жилья по социальной норме, причем не 
только в городе, но и на селе. Это неудивительно, учитывая близкое знакомство граждан нашей страны с проблемами ипотеки и кредитования в целом, а также тот факт, что выплат по семейному капиталу (как федеральному, так и, тем более, региональному), на приобретение жилья в большинстве регионов не хватает. Укладывается такая оценка и в теоретические представления о патерналистских ожиданиях значительной части российских граждан, предпочитающих от государства именно монетарные выплаты [Зеленкова, Чернова 2012].

Обращает внимание относительно негативная оценка некоторыми категориями респондентов (потенциальных родителей, по их собственному утверждению, как указано в методологии отбора респондентов) мер, открыто направленных на поддержание рождения третьего ребенка и последующих детей, что особенно заметно именно в графиках, учитывающих число не только уже имеющихся у людей детей, но и желаемых ими при благоприятных обстоятельствах. Возможно, те, кто выбрал для себя модель «семья только с одним ребенком» или «семья только с двумя детьми», отрицают такие меры, как направленные не на них. На наших графиках особенно четко это прослеживается у женщин в целом и у городских женщин. Это соответствует результатам, полученным другими исследователями [Андреев, Захаров 2017; Синявская, Бирюкова, Фаттахова 2015].

Более молодые люди относительно более позитивно оценивают все меры. Можно предположить, что это связано с оптимизмом, присущим молодости, а также с недостатком у них жизненного опыта (например, заметно падение оценки очень многих мер при наличии У респондента хотя бы одного ребенка).

Такая мера, как гибкий график, в том числе и работа дистанционно на дому (хотя некоторые исследователи предполагали обратное [Елизаров, Левина 2015]), является аутсайдером в оценках при любых распределениях, особенно ярко это проявляется у мужчин (но и у женщин тоже). Это может быть связано с тем, что люди не верят, что при такой организации труда смогут достаточно заработать, при этом осознают трудности, которые будут связаны с попыткой одновременно работать из дома и полноценно без помощников растить в этом же доме детей, хорошо знакомые всем, кто когда-либо пытался это делать. Вообще патерналистские ожидания и предпочтение монетарных выплат респондентами можно связать с достаточно низкой средней официальной зарплатой в России, не в полной мере и не всем позволяющей удовлетворить нужды семьи при попытках заработать деньги самостоятельно.

Респонденты в целом оценивают выше меры, связанные с прямой и понятной денежной выплатой, такие как беспроцентная ссуда (это деньги, получаемые сразу, а как их потом придется возвращать, можно пока не задумываться, и ведь проценты не будут нарастать), федеральный и региональный семейные капиталы, ежемесячные выплаты на каждого ребенка до трех лет и ежемесячные выплаты на третьего и последующих детей в размере прожиточного минимума. Место в детском саду оценивается почти так же высоко, но все-таки несколько ниже (особенно высоко -молодыми и пока бездетными женщинами). Впрочем, ежемесячные выплаты на ребенка оцениваются ими так же: вероятно, женщины хотели бы иметь возможность выбирать, сидеть ли с ребенком дома или отдать его в 
детский сад, при том, что обе альтернативы поддерживались бы государством. Это соответствует предположениям, высказанным в докладе Елизарова и Левиной [2015].

Такая опция, как выделение земли под строительство дома, оценивается противоречиво: горожанами, а также ориентированными на меньший размер семьи - более низко, ориентированными на многодетность - более высоко. Интересно, что не так уж высоко ее оценивают сельские жители, например, сельские мужчины с возрастом начинают считать эту меру все менее привлекательной. Такие различия в оценках неудивительны, поскольку сама по себе земля не означает, что у людей автоматически откуда-то появляются время, деньги и силы на то, чтобы строить на ней дом, да и не все так уж хотят такой дом. К тому же большую роль играет неопределенность места, в котором будет расположен выделяемый участок земли.

Налоговые льготы, возможная перспективность которых подчеркивалась в [Елизаров, Левина 2015], почти всеми проанализированными категориями оцениваются почти так же низко, как гибкий график, несколько выше - только городскими мужчинами 40-49 лет. Видимо, только этот сегмент достаточно часто работает не в сером секторе экономики, в то время как, например, сельские и формально неработающие мужчины, а также большинство женщин, не видят в этой мере для себя преимуществ либо потому, что действительно не работают, либо в связи с неофициальностью своей работы.

В группах женщин с образованием не выше 9 классов средней школы некоторые признаки позволяют выделить существование модели «семья не более чем с тремя детьми»; интересно, что у более высокообразованных женщин такая модель не выделяется. Женщины, ориентированные на большее число детей, конечно, существуют, но их, вероятно, немного, и их характеристики индивидуальны, по крайней мере в тех «координатах», которые задают исследуемые нами меры семейной политики.

В целом наш анализ позволяет предположить, что наиболее интересной, универсальной и перспективной мерой из числа предложенных могла бы быть именно беспроцентная ссуда на приобретение жилья. Принимающим решения в области семейной политики, возможно, стоило бы подумать и разработать конкретные механизмы проведения ее в жизнь (выделение суммы уже при рождении первого ребенка; сроки платежей; ежемесячные платежи в некоем фиксированном размере; погашение части задолженности при рождении каждого ребенка, так, чтобы, например, при рождении ребенка определенной очередности можно было эти деньги не возвращать совсем и др.).

Важно также, чтобы эта мера не оказалась единственной. Привлекательны для респондентов также ежемесячное пособие для всех детей до трех лет и гарантированное место в детском саду, яслях, что позволило бы людям выбирать образ жизни при рождении ребенка и возможность сосредоточиться или на заработке, или на собственно родительстве.

Стимулирующий потенциал гибкого графика (надомной работы) и налоговых льгот родителям, исходя их нашего анализа, невелик. Выплаты, акцентирующие свою направленность именно на третьего ребенка, похоже, скорее отталкивают некоторых потенциальных родителей. Федеральный и региональный семейные капиталы сохраняют 
свою привлекательность, но уступают беспроцентной ссуде, как мере более конкретной и в отличие от них более полно решающей хотя бы одну из проблем семей (жилищную).

\section{ЛИТЕРАТУРА}

Андреев Е.М. (2012). О точности результатов Российских переписей населения и степени доверия к разным источникам информации // Вопросы статистики.11: 21-35.

Андреев Е.М., С.В. Захаров (2017). Микроперепись-2015 ставит под сомнение результативность мер по стимулированию рождаемости // Демоскоп Weekly. 711-712. URL: http://demoscope.ru/weekly/2017/0711/tema01.php (дата обращения: 07.12.2017).

Варламова С.Н., А.В. Носкова, Н.Н. Седова (2006). Семья и дети в жизненных установках россиян // Социологические исследования.10: 61-73.

Доклад об основных итогах федерального статистического наблюдения «Социальнодемографическое обследование (микроперепись населения) 2015 года» (2016). М.: Росстат.

Елизаров В., В. Левина (2015). Проект «Старение населения в Российской Федерации»: Семейная политика в России: возможно ли замедление старения населения путем мер, направленных на повышение уровня рождаемости» // Рабочий доклад World Bank. URL: http://documents.worldbank.org/curated/en/892801468196750951/pdf/99503RUSSIAN-PUBLIC-Family-Policies-in-Russia-final-cover-Russian-final.pdf (дата обращения: 12.07.2018).

Захаров С.В. (2016а). Скромные результаты пронаталистской политики на фоне долговременной эволюции рождаемости в России. Часть $1 / /$ Демографическое обозрение. 3. 3: 6-38.

Захаров С.В. (2016b). Скромные результаты пронаталистской политики на фоне долговременной эволюции рождаемости в России. Часть 2 // Демографическое обозрение. 3. 4: 6-26.

Зеленкова Ю., Ж. Чернова (2012). Патернализм современной российской семейной политики: позиция государства и ожидания граждан // Человек, Сообщество, Управление. 4: 96-110.

Исупова О.Г. (2016). Семейная политика в развитых странах // Демоскоп Weekly. 701-702. URL:http://demoscope.ru/weekly/2016/0701/demoscope701.pdf (дата обращения: 07.07.2018).

Исупова О.Г. (2017). Чему учит опыт семейной политики // Демоскоп Weekly. 739-740. URL: http://demoscope.ru/weekly/ 2017/0739/tema01.php (дата обращения: 07.07.2018 ).

Кучмаева О.В. (2017). Современные проблемы оценки эффективности семейной политики в Российской Федерации // Статистика и экономика. 14. 5: 85-93.

Малева Т., А. Макаренцева, Е. Третьякова (2017). Пронаталистская демографическая политика глазами населения: десять лет спустя // Экономическая политика. 12. 6: 124 147.

Серегина Л.В. (2012). Профессиональное обучение - гарантия содействия трудоустройству // Журнал российского права. 2: 26-35.

Синявская О.В., С.С. Бирюкова, А.А. Фаттахова (2015). Влияние новых мер российской демографической политики на вероятность рождения вторых и последующих детей // 
Демоскоп Weekly. 625-626. URL:

http://www.demoscope.ru/weekly/2015/0625/analit05.php (дата обращения: 07.12.2017).

Слонимчик Ф., А. Юрко (2015). Оценка влияния политики материнского капитала в России // Демографическое обозрение. 2. 3: 30-68.

Тындик А. (2010). Обзор современных мер семейной политики в странах с низкой рождаемостью // Социальная политика: экспертиза, рекомендации, обзоры. 12: 157177.

Caldwell J.C., P. Caldwell, P. McDonald (2002). Policy responses to low fertility and its consequences: A global survey // Journal of Population Research. 19(1): 1-24.

Chesnais J.-C. (1985). Les conditions d'efficacité d'une politique nataliste: examen théorique et exemples historiques // Proceedings of the IUSSP International population conference. Florence: IUSSP: 413-425.

Ekert O. (1986). Effets et limites des aides financières aux familles: une expérience et un modèle // Population. 41(2): 327-348.

Esping-Andersen G. (1990). The three worlds of welfare capitalism. Cambridge: Polity Press: 954.

Gauthier A.H. (2002). Family policies in industrialized countries: Is there convergence? // Population (English edition). 57: 447-474.

Kaufmann K. X. (2002). Politics and policies towards the family in Europe: A framework and in inquiry into their differences and convergences // Family Life and Family Policies in Europe. Vol. 2: Problems and Issues in Comparative Perspective / F.-X. Kaufmann et al., eds.

Oxford: Clarendon Press: 419-490.

Teitelbaum M.S. (2006). History of population policies / G. Caseli, J. Vallin, G. Wunsh, eds. // Demography: Analysis and Synthesis. A Treatise in Population. Ch. 100. Academic Press: 71-82.

Thevenon O. (2008). Les politiques familiales des pays développés : des modèles contrastés // Population et societies. 448: 1-4. 


\title{
ATTITUDES TO PRONATALIST POLICY MEASURES ACCORDING TO THE DATA OF THE 2015 MICRO-CENSUS
}

\author{
$\underline{\underline{\text { OLGA ISUPOVA }}}$
}

\begin{abstract}
The article aims to evaluate the possible motivational potential (in terms of having more children than planned) of various measures of family policy listed in the questionnaire of the Russian Microcensus-2015. During the last several decades, fertility in Russia has been below the level of simple reproduction. The state, starting in 2005, has expressed an interest in finding effective measures to raise fertility in the country. The latest Microcensus had, among other objectives, the goal of "testing" the attractiveness of different policy measures for the general population. These included both already existing policies (federal and regional "maternity capitals", land grants) and those which were hypothetical at the moment (prolongation of paid childcare leave until the child reaches the age of three, a guaranteed place in kindergarten, benefits equal to the cost of living for every child starting from the third, tax benefits, flexible working hours/work from home, and interest-free loans for the purchase of housing).
\end{abstract}

Our research was conducted using methods of descriptive statistics, since data at the individual level were not available on the Microcensus site. We studied differences in the perception of the proposed measures by gender, age, education level, numbers of already existing and desired children, and employment status. The research showed a possible clustering of women (and probably men as well) into those who intend to have just one, two or three children. Measures focused on a third child were of no interest to the first and second groups of respondents. The interest-free housing loan was found to be the most popular measure among virtually all groups of respondents. On the whole, measures having a paternalistic character were perceived positively, while the least attractive measures included work from home and tax benefits. This is probably due to the fact that the former is associated with lower earnings, and the latter are relevant only to those who work in the official sector of the economy. An intention to have three children can be observed mostly among women with lower education and in rural areas.

Key words: Russian Microcensus-2015, analytic limitations, reproductive intentions, family policy, effectiveness.

Olga Isupova (oisupova@hse.ru), NATIONAL ResEARCh University Higher SchOol of Economics, Russia.

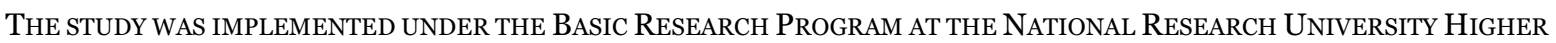
SCHOOL OF ECONOMICS (HSE) IN 2017. PROJECT "THE LONG-TERM DEMOGRAPHIC DEVELOPMENT OF RUSSIA IN THE LIGHT OF THE 2015 MICROCENSUS RESULTS".

DATE RECEIVED: MAY 2018.

\section{REFERENCES}

Andreev E.M (2012). O tochnosti rezul'tatov Rossiyskikh perepisey naseleniya i stepeni doveriya $\mathrm{k}$ raznym istochnikam informatsii [On the accuracy of the results of Russian population censuses and the level of confidence in different sources of information] // Voprosy statistiki [Issues of Statistics]. 11: 21-35.

Andreev E.M., S.V. Zakharov (2017). Mikroperepis'-2015 stavit pod somnenie rezul'tativnost' mer po stimulirovaniyu rozhdaemosti [Microperepis-2015 puts under question the efficiency of measures to stimulate fertility] // Demoscop Weekly [Demoscope Weekly]. 711-712. URL: http://demoscope.ru/weekly/2017/0711/tema01.php (accessed: 07.12.2017).

Caldwell J.C., P. Caldwell, P. McDonald (2002). Policy responses to low fertility and its consequences: A global survey // Journal of Population Research. 19(1): 1-24. 
Chesnais J.-C. (1985). Les conditions d'efficacite d'une politique nataliste: examen theorique et exemples historiques // Proceedings of the IUSSP International population conference. Florence: IUSSP: 413-425.

Doklad ob osnovnykh itogakh federal'nogo statisticheskogo nablyudeniya «Sotsial'nodemograficheskoe obsledovanie (mikroperepis' naseleniya) 2015 goda» [The report on main results of federal statistical observation «Social and demographic investigation (population microsensus) 2015»] (2016). Moscow: Rosstat.

Ekert O. (1986). Effets et limites des aides financieres aux familles: une experience et un modele // Population. 41(2): 327-348.

Elizarov V.V., V. Levina (2015). Proekt «Starenie naseleniya v Rossiyskoy Federatsii»: Semeynaya politika v Rossii: vozmozhno li zamedlenie stareniya naseleniya putem mer, napravlennykh na povyshenie urovnya rozhdaemosti» [Family Policies in Russia: Could Efforts to Raise Fertility Rates Slow Population Aging?] // Rabochiy doklad World Bank [Work Report]. World Bank, Washington, DC. World Bank. URL: http://documents.worldbank.org/curated/en/892801468196750951/pdf/99503-RUSSIANPUBLIC-Family-Policies-in-Russia-final-cover-Russian-final.pdf (accessed: 12.07.2018).

Esping-Andersen G. (1990). The Three Worlds of Welfare Capitalism. Cambridge: Polity Press: 9-54.

Gauthier A.H. (2002). Family policies in industrialized countries: Is there convergence? // Population (English edition). 57: 447-474.

Isupova O.G. (2016). Semeynaya politika v razvitykh stranakh [Family policy in developped countries] // Demoscop Weekly [Demoscope Weekly]. 701-702.

URL:http://demoscope.ru/weekly/2016/0701/demoscope701.pdf (accessed: 07.07.2018).

Isupova O.G. (2017). Chemu uchit opyt semeynoy politiki [What the experience of family policy does teach us] // Demoscop Weekly [Demoscope Weekly]. 739-740. URL: http://demoscope.ru/weekly/ 2017/0739/tema01.php (accessed: 07.07.2018).

Kaufmann K. X. (2002). Politics and policies towards the family in Europe: A framework and in inquiry into their differences and convergences // Family Life and Family Policies in Europe. Vol. 2: Problems and Issues in Comparative Perspective / F.-X. Kaufmann et al., eds. Oxford: Clarendon Press: 419-490.

Kuchmaeva O.V. (2017). Sovremennye problemy otsenki effektivnosti semeynoy politiki v Rossiyskoy Federatsii [Contemporary problems of evaluation of family policy efficiency in Russian Federation] // Statistika i ekonomika [Statistics and Economics]. 14. 5: 85-93.

Maleva T., A. Makaretseva, E. Tretyakova (2017). Pronatalistskaya demograficheskaya politika glazami naseleniya: desyat' let spustya [Pronatalist demographic policy from the viewpoint of population: ten years after] // Ekonomicheskaya politika [Economic Policy]. 12. 6: 124-147.

Seregina L.V. (2012). Professional'noe obuchenie - garantiya sodeystviya trudoustroystvu [Vocational training - a guarantee of employment promotion] // Zhurnal rossiyskogo prava [Journal of Russian Law]. 2: 26-35.

Siniavskaya O.V., S.S. Birukova, A.A. Fattakhova (2015). Vliyanie novykh mer rossiyskoy demograficheskoy politiki na veroyatnost' rozhdeniya vtorykh i posleduyushchikh detey [Influence of new measures of Russian demographic policy on probability of birth of second and higher order children] // Demoscop Weekly [Demoscope Weekly]. 625-626. URL: http://www.demoscope.ru/weekly/2015/0625/analit05.php (accessed: 07.12.2018). 
Slonimchik F., A. Yurko (2015). Otsenka vliyaniya politiki materinskogo kapitala v Rossii [Evaluation of the influence of Maternal Capital policy in Russia] // Demographicheskoe obozrenie [Demographic Review]. 2. 3: 30-68.

Teitelbaum M.S. (2006). History of population policies / G. Caseli, J. Vallin, G. Wunsh, eds. // Demography: Analysis and Synthesis. A Treatise in Population. Ch. 100. Academic Press: 71-82.

Thevenon O. (2008). Les politiques familiales des pays développés: des modèles contrastés // Population et societies. 448: 1-4.

Tyndik A. (2010). Obzor sovremennykh mer semeynoy politiki v stranakh s nizkoy rozhdaemost'yu [A review of contemporary measures of family policy in the countries with low fertility] // Sotsialnaya politika: expertiza, rekomendatsii, obzory [Social policy: expertize, recommendations, reviews]. 12: 157-177.

Varlamova S.N., A.V. Noskova, N.N. Sedova (2006). Sem'ya i deti v zhiznennykh ustanovkakh rossiyan [Family and children in Russians` life attitudes] // Sotsiologicheskie issledovaniya [Sociological Research]. 10: 61-73.

Zakharov S.V. (2016a). Skromnye rezul'taty pronatalistskoy politiki na fone dolgovremennoy evolyutsii rozhdaemosti $v$ Rossii [Moderate results of pronatalist policy on the background of longterm evolution of fertility in Russia]. Chast' 1 [Part 1] // Demographicheskoe obozrenie [Demographic Review]. 3. 3: 6-38.

Zakharov S.V. (2016b). Skromnye rezul'taty pronatalistskoy politiki na fone dolgovremennoy evolyutsii rozhdaemosti v Rossii [Moderate results of pronatalist policy on the background of longterm evolution of fertility in Russia]. Chast' 2 [Part 2] // Demographicheskoe obozrenie [Demographic Review]. 3. 4: 6-26.

Zelikova Yu., Zh. Chernova (2012). Paternalizm sovremennoy rossiyskoy semeynoy politiki: pozitsiya gosudarstva i ozhidaniya grazhdan [Paternalism of modern Russian family policy: state position and citizens`s expectations] // Chelovek, Soobshchestvo, Upravlenie [Human, Community, Management]. 4: 96-110. 